\title{
PATENT COLlateral, InVESTOR COMMITMENT, AND THE MARKET FOR VENTURE LENDING ${ }^{*}$,
}

\author{
Yael V. Hochberg \\ Rice University, MIT \& NBER \\ Carlos J. Serrano \\ Universitat Pompeu Fabra, Banco de España, Barcelona GSE, \& NBER \\ Rosemarie H. Ziedonis \\ University of Oregon
}

This version: October 7, 2014

\begin{abstract}
The use of debt to finance risky entrepreneurial-firm projects is rife with informational and contracting problems. Nonetheless, we document widespread lending to startups in three innovation-intensive sectors and in early stages of development. At odds with claims that the secondary patent market is too illiquid to shape debt financing, we find that intensified patent trading increases the annual rate of startup lending, particularly for startups with more redeployable (less firm-specific) patent assets. Exploiting differences in venture capital (VC) fundraising cycles and a negative capital-supply shock in early 2000 , we also find that the credibility of $\mathrm{VC}$ commitments to refinance and grow fledgling companies is vital for such lending. Our study illuminates friction-reducing mechanisms in the market for venture lending, a surprisingly active but opaque arena for innovation financing, and tests central tenets of contract theory.
\end{abstract}

Keywords: Entrepreneurial Finance, Financial Intermediation, Market for Patents, Venture Capital, Venture Lending

JEL classification: L14, L26, G24, O16, O3

* We thank Dow Jones Venture Source and Sand Hill Econometrics for venture finance and startup-exit data, RPX Corp for data on patent transactions, and Andre Boik, Jing Li, Karina Mann, Junguang Pan, Anastasia Strader, and Shana Wang for excellent research assistance. We also thank the venture lenders, investors and entrepreneurs who shared time and insights with us, Angela Cipollone, Alfonso Gambardella, David Hsu, Katherine Litvak, and Marvin Lieberman for discussant comments, and numerous colleagues and seminar participants for feedback and suggestions. Financial support from the NBER Innovation Policy Working Group and the University of Michigan Program in Law, Economics and Technology is gratefully acknowledged. All errors are our own. The opinions in this article are the sole responsibility of the authors and they do not necessarily coincide with those of the Banco de España.

†Contact information: hochberg@mit.edu; carlos.serrano@upf.edu; rmz@uoregon.edu 


\section{Introduction}

Economic theory generally views external debt as an unlikely vehicle for financing the innovative activities of companies, particularly in early stages of their development (Leland and Pyle, 1977; De Meza and Webb, 1987). While the use of loans to finance research and development projects allows entrepreneurs to avoid additional dilution of their ownership stakes, convincing outsiders to supply loans for risky entrepreneurial-firm projects can be difficult due to informational and contracting frictions. The market value of innovative companies often rests on intangible assets that are difficult to value ex ante and hard to sell ex post. Equally challenging, the path to commercialization involves substantial risk and is fraught with hazards. Absent tangible assets or positive cash flows to secure a loan, equity arrangements with venture capitalists offer a more natural solution to the entrepreneurial financing problem (Hall and Lerner, 2010).

Although technology startups and outside debt seem poorly suited for one another, recent evidence suggests that the market for lending to startups (often referred to as "venture lending") is large and active. Ibrahim (2010) estimates that venture lenders, including leader Silicon Valley Bank and specialized non-bank lenders, supply $\$ 5$ billion to startups annually. ${ }^{1}$ In a recent survey, Robb and Robinson (2014) similarly report a "surprisingly high" debt reliance by startups with external equity owners, with loans representing 25 percent of the startup capital for 200 growthoriented companies. Yet we know little about the workings of this market and the forces shaping it.

This study investigates the venture lending market - a seemingly important yet under-studied source of entrepreneurial capital—and explores factors that facilitate trade within it. Drawing on incomplete contracting and financial intermediation theory, we explore two potential frictionreducing mechanisms: (1) increased liquidity in the secondary market for patent assets, which could alter lender expectations of salvage value, and (2) the ability of an intermediary (here, the venture capitalist) to credibly convey to a lender that he/she will support the fledgling company.

Examining the market for venture lending poses a number of challenges. The most significant of these is the nature of the available data. As Ibrahim (2010) notes, venture debt transactions and information about the parties involved are sparsely reported. Regulators do not require venture lenders to publicly disclose information about their loans. Venture loans also are rarely syndicated,

1Venture lending typically refers to arm's length (formal) loans supplied by banks and other for-profit financial institutions, often to science and technology startups. Ibrahim's market size estimates therefore do not include loans from government agencies or from "insiders" (e.g., bridge loans from investors or alliance partners). 
which reduces coverage in lending databases such as DealScan. Conversations with lenders further suggest that these transactions are not systematically reported in standard venture capital databases.

In light of these challenges, we use an alternative approach developed in Serrano (2010) that identifies debt through patents, a common form of collateral used to secure the loans. Venture lenders typically require a blanket lien on assets, including but not limited to patents (Mann, 1997; Gordon, 2013). When the collateral includes patents, lenders have strong incentives to record the security interest with the U.S. Patent and Trademark Office (USPTO) both in order to establish their secured-lender status and to convey the lien on assets to other potential lenders (Haemmeli, 1996; Mann, 1997). ${ }^{2}$ We use this paper trail of recordation to map startups to loans through patents, thus revealing startup-level lending difficult to glean from other sources.

We document widespread lending to new science and technology companies, even in the very early stages of their development. Our evidence is based on the population of venture capital (VC)backed startups founded from 1987 through 1999 in three innovation-intensive sectors: computer software, semiconductors, and medical devices. Of 1,519 such startups with patents at risk for use in lending, 36 percent used patents to secure loans by 2008 or prior to exit. The proportion of sample startups receiving debt each year climbs steadily over time, is lowest before a startup receives its first VC equity infusion (independent of age), and is highest when equity investment is made by top-tier investors. Based on sector-level measures that we compile on the intensity of patent trading, we also observe close tracking between lending activity within the sample and the thickness of trade in the broader market for patents, particularly in the software sector.

Importantly, the empirical patterns we document suggest that startup lending is stimulated both by intensified patent trading and VC-level factors. In baseline estimates of the annual likelihood that a startup will receive a patent-secured loan, we include numerous time-varying controls as well as startup fixed effects, thus differencing out permanent startup characteristics that could affect lending (e.g., wealthy founders). Even with this more stringent test, an increase in the intensity of patent trading predicts a significant upward shift in a startup's annual likelihood of receiving a loan. If this effect is due to a shift in lender expectations of the salvage value of patents, as incomplete contracting theory suggests, activity in the collateral asset market should disproportionately boost lending to startups with patents that are more redeployable to alternative uses or users (Williamson 1988; Shleifer and Vishny, 1992; Benmelech and Bergman 2008, 2009;

\footnotetext{
${ }^{2}$ In bankruptcy, secured creditors are first in line to be paid; only then are any remaining funds dispersed to other claimants. Recording the lien "acts as insurance" for lenders in event of debtor failure (Menell, 2007).
} 
Gavazza, 2011). Consistent with a salvage-value interpretation, this distinctive pattern is present in the data.

Exploiting differences in VC fundraising cycles and a negative capital-supply shock, we further test a core prediction from Holmstrom and Tirole (1997): that a VC's ability to credibly convey his/her commitment to monitor and support an entrepreneurial firm facilitates lending to otherwiserisky companies. As Townsend (2012) and others document, the collapse of the U.S. "technology bubble," commonly pegged to an unprecedented drop in the value of Nasdaq shares in March 2000, led to an unexpectedly severe and prolonged decline in the supply of institutional capital to the VC asset class, particularly in information technology (IT)-related sectors. Given lumpiness in the VC fundraising process, this shock should impose more binding near-term constraints on VCs that were attempting to fundraise at the time of the shock but had not yet closed a fund, or those that were near to going out to fundraise for a new fund. We therefore use the vintage of funds managed by a startup's investors as of early 2000 as a source of variation that affects the credibility of VC commitment and implicit promise to repay lenders post-crash for reasons plausibly exogenous to the quality of a startup previously selected for VC funding.

The results are striking. Following the technology bubble's collapse, lending to startups with less capital-constrained investors (i.e., those that had recently closed funds as of early 2000) continued apace, increasing slightly to a per annum rate of 13 percent by 2002. In sharp contrast, lending to startups with more constrained investors (i.e., those that had not recently fundraised at the time of the bubble collapse) plummeted, from an average rate of 17 percent in the three-year run-up period to a mere 1.5 percent three years following the crash. The estimates are based on sample IT companies active and independent during the entire six-year window surrounding the shock, and therefore are not explained by differences in time to exit. In more formal difference-indifference (DD) tests, we show that the before-and-after shift in lending remains large in magnitude and is statistically significant, even after we allow permanent and numerous time-varying startup characteristics to affect the baseline likelihood of lending. Prior to the shock, the two groups of startups exhibit comparable trend-lines in the annual rate of lending. Also reassuring for our empirical strategy, placebo tests reveal differential sorting only in contexts within our sample (IT startups in the crisis period) where differences in VC fundraising cycles likely impose binding constraints on the near-term sourcing of capital.

Evidence from our difference-in-differences analysis suggests that, through the credibility of their commitments to support young companies, VCs play a vital intermediary role in the debt 
financing of risky entrepreneurial-firm projects. Post-crash, lenders continued to finance startups backed by investors with less binding capital constraints, but withdrew from otherwise-promising projects that may have needed their funds the most. This "flight-to-safety" finding is highly salient for ongoing policy initiatives to stimulate entrepreneurial-firm innovation through lending channels (Harhoff, 2009; Hall and Lerner, 2010). Absent a well-developed infrastructure of VC intermediaries and institutional capital providers, the effects of such initiatives could be muted.

The study relates to a growing literature on innovation financing through loans (e.g., Kerr and Nanda, 2009; Chava et al., 2013; Cerqueiro et al. 2014). ${ }^{3}$ In contemporaneous work, Mann (2014) reports that debt secured by patents is an important source of financing for R\&D performed by established firms. We document pervasive lending activity in a context where its use is particularly surprising-young innovation-oriented companies. In doing so, we contribute to a small literature on venture debt, much of which is by legal scholars (Mann, 1997, 1999; Ibrahim, 2011). Analyzing debt rounds in VentureOne, Chakraborty and Ewens (2012) report that startups use debt in response to adverse shocks, such as failed clinical trials or missed milestones. Robb and Robinson (2014) document, through a survey of companies founded in 2004, that debt is a more common form of financing for growth-oriented startups than previously thought. We trace startup-level lending activity over a three-decade period, and provide novel evidence on mechanisms that facilitate trade within the venture lending market.

A related literature in entrepreneurial finance and strategy examines whether and how VCs "add value" to startups beyond their abilities to identify and attract more promising ventures, an important line of inquiry that is notoriously tricky to pinpoint with observational data. Based on offers that entrepreneurs receive from VCs in their initial rounds of financing, Hsu (2004) shows that entrepreneurs pay a premium to affiliate with top-tier investors, suggesting that entrepreneurs anticipate receiving more value-added from these investors. Others document that VCs add value by guiding and professionalizing young firms (e.g., Lerner, 1995; Hellman and Puri, 2002; Chemmanur et al., 2011) and providing access to superior resource networks (e.g., Hsu, 2006; Hochberg et al., 2007; Hegde and Tumlinson, 2014). Complementing this work, we highlight an intermediary role of VCs that has received limited attention in this literature-opening access to debt channels of financing — and devise a lever for identifying its effects.

Finally, the study contributes to a separate strand of research on trade in patent markets and its implications for innovative activity. Lamoreaux and Sokoloff (1999) report that historic markets for

\footnotetext{
${ }^{3}$ Hall and Lerner (2010) provide a thoughtful review of earlier work on this topic.
} 
buying and selling patents allowed inventors to specialize in the generation of new ideas sold to others for commercialization, potentially leading to efficiency gains in technology production as in Arora, Fosfuri and Gambardella (2001). Serrano (2010) and Galasso et al. (2013) document active trading in the modern market for patents, particularly for inventions originating from individuals and small companies. The implications of patent trading for innovation financing is unexplored in prior research, a gap that this study helps fill.

The remainder of this paper is organized as follows. We first discuss relevant insights from the incomplete contracting literature and their relevance for venture lending. We then describe the sample and data used in the study. Finally, we present and discuss our empirical analysis and findings.

\section{Theoretical Framework and Background}

\subsection{Collateral Assets, Intermediaries, and the Debt Financing of Startup Innovation}

An extensive theoretical literature suggests that financing the innovation activities of new firms through formal debt is problematic. A common reason is financial frictions between lenders and debtors due to information asymmetries, which can reduce access to debt (Leland and Pyle, 1977; Stigliz and Weiss, 1981; De Meza and Webb, 1987). Among the mechanisms for reducing such frictions, collateral posting and financial intermediation have received prominent theoretical attention.

Turning first to collateral posting, lenders typically demand collateral assets because the threat of asset liquidation can increase the debtor's motives to avoid default, reducing the risk of the loans (Johnson and Stulz, 1985). ${ }^{4}$ In the event that the debtor fails to repay the loan, lenders also have the legal right to seize and sell the collateral assets to offset losses. The amount that creditors expect to recover upon seizure of the collateral (i.e., the expected "liquidation" or "salvage" value of the assets) should thereby affect their incentives to lend (Williamson, 1988; Shleifer and Vishny, 1992).

The incomplete contracting literature typically assumes that lender expectations of salvage value are shaped by two inter-related factors: (1) trading conditions in the secondary market for collateral assets such as the number of potential buyers and the costs associated with finding them; and (2) whether the assets pledged are firm-specific (e.g., tied to the human capital or commercial pursuits of the debtor) or likely to retain value if redeployed to alternative uses or users

\footnotetext{
${ }^{4}$ See also Ueda (2004) and De Bettignies (2008).
} 
(Williamson, 1988). To elaborate, Benmelech and Bergman $(2008,2009)$ and Gavazza (2011) show that thicker trading (increased "liquidity") in the resale market for collateral assets increases liquidation values and, in turn, stimulates lending. When buyers are few and/or costly to locate, trading frictions reduce the gains anticipated from an exchange and lower asset prices. In thicker re-sale markets, matching between sellers and buyers is more efficient; in turn, lenders expect more value to be retained in the event of exchange (Gavazza, 2011). If assets are highly firm-specific, however, their redeployment value is more limited by definition (Williamson, 1988). In this event, the effects of trading activity in the broader resale market should diminish. Consistent with this view, Benmelech (2008) finds that railroad companies with standard-width rather than site-specific track gauges (i.e., with more redeployable assets for use as collateral) were better able to obtain debt financing during the mid-1870s economic depression. Similarly, Benmelech and Bergman (2009) report a higher debt capacity for U.S. airlines that operate less specialized (more redeployable) fleets.

A second mechanism - an intermediary's credible commitment to monitor the risky venturecan also alleviate informational frictions with lenders. In a financial intermediation theory, Holmstrom and Tirole (1997) model lending transactions that involve firms (entrepreneurs), informed intermediaries (venture capitalists), and uninformed outsiders (lenders). The entrepreneur's borrowing capacity is limited as is the intermediary's capital. The entrepreneur may lack the skills or incentives to manage projects diligently. Although the intermediary (VC) can monitor and guide the entrepreneur, his/her efforts are unobservable to the lender, thus creating a moral hazard problem. As Holmstrom and Tirole (1997) show, an injection of capital by the intermediary is required to credibly convey to the lender that he/she will exert the effort to monitor the company: the intermediary, in seeking a return on its investment, has an incentive to engage in the unobservable effort to build and oversee the project. ${ }^{5}$ In turn, financial frictions arising from information asymmetries between the entrepreneur and uninformed outsider (lender) are reduced.

Of particular importance for our analysis, Holmstrom and Tirole (1997) further show that a negative shock to the capital supply, in which the availability of capital to financial intermediaries is reduced for reasons largely beyond their control, will limit debt access for entrepreneurial firms backed by those intermediaries. The intuition is simple. Less capital can be injected into the

${ }^{5}$ In Williamson $(1983,1988)$, equity infusions similarly serve as an incentive-alignment function, by "credibly committing" contracting parties to an endeavor. More recently, Nanda and Rhodes-Kropf (2014) argue that the impact of financing risk, i.e., the risk that later stage investors will not fund a startup even if fundamentals are still sound) on a startup can be reduced by injecting into the startup more money up front (or committing to fund). 
companies because the supply of capital to intermediaries is limited. As a result, financial intermediaries will find it more difficult to credibly convey to the lenders that they will continue to support the portfolio company, thus making it more difficult for the company to secure a loan.

\subsection{Implications for Venture Lending}

Financing the risky projects of entrepreneurial firms with outside debt is a situation rife with informational and contracting frictions. Success rests on entrepreneurial and managerial effort that is difficult for lenders to specify ex ante and monitor ex post, and commercialization requires upfront investments in projects likely to fail. As Lundqvist and Richardson (2003) report, the average VC fund raised between 1981 and 1993 wrote-off more than 75 percent of its portfoliocompany investments.

Challenges aside, parties involved in a typical venture lending transaction, lenders plus entrepreneurs and/or their investors, have much to gain from striking a deal. Venture lenders stand to earn interest on the loans, with bank-lenders earning additional fees for banking services rendered. ${ }^{6}$ For entrepreneurs and their investors, the main attraction is funding that does not require costly dilutions of equity. In turn, they gain added financial cushion, potentially increasing their abilities to maneuver in the event of commercialization setbacks or milestone delays. As depicted in Figure 1, venture debt is therefore marketed as a way to "extend the financial runway" of a startup (Gordon, 2013). The obvious drawback is the need to repay the loans plus interest within an agreed-upon time frame. In the event of default, entrepreneurs also stand to lose control over assets used to secure the loan, including patented inventions.

What mechanisms facilitate trade in the venture lending market? Industry descriptions and case studies highlight the importance of VC involvement (Mann, 1999; Ibrahim, 2010). Hardymon, Lerner and Leamon $(2005, \mathrm{p} 4)$ aptly describe the VC role as follows:

'Lenders rel[y] both on the investors' ability to choose good firms and on their presumed willingness to support the investments with future funding, and thus tried to maintain a good relationship with the best venture capitalists. Further reducing the risk, the loan usually closed just after a major equity infusion, increasing the possibility that the debt would be paid off before the company's money ran out."

\footnotetext{
${ }^{6}$ Non-bank organizations in the venture debt landscape include specialized lenders like Lighthouse Capital, Hercules Technology Growth Capital, and Western Technology Investment. Banks tend to provide smaller loans, typically ranging up to \$2-3 million, at lower interest rates than non-banks. Banks typically require borrowers to deposit cash and use other financial services, thus producing a secondary source of revenues from fees while providing a monitoring function (of tracking changes in burn rates) for VC investors. Non-banks face less stringent regulatory restrictions than banks. In turn, specialized non-bank lenders typically incur higher risk, charge higher interest rates, and have higher maximum loan packages reaching the tens of millions.
} 
As in other accounts of the industry (Mann, 1997; Ibrahim, 2010) and our conversations with lenders, Hardymon et al. (2005) report that lenders outsource much of the due-diligence and valuation process to VCs, both for the applicant startup and its intangible assets. The quote further suggests that VC reputation (skill) is informative for lenders, both for ex ante (ability to identify and attract more promising startups) and ex post (ability and willingness to support the startup once funded) reasons. ${ }^{7}$ In either case, this discussion suggests that venture capitalists help "harden" soft assets - technologies, skills, and other intangibles like patents - that startups would find more difficult to borrow against on their own.

Ironically, by seeking payment from follow-on rounds of $\mathrm{VC}$ financing, venture lenders also may lower risks by funding startups in earlier stages of development, when VCs are more likely to secure follow-on resources for the company (Puri and Zarutskie, 2012). As a venture lender interviewed by Levin (2008) reports, venture debt [in contrast to equity-based venture capital] is "a game of strikeouts, singles, and doubles, rather than home runs... The trick is not to strikeout too often."

Whether lending activity is shaped by expectations of the salvage value of patent collateral is more ambiguous. Legal scholars report that lenders consider the tradable (salvage) value of patents when crafting loans, despite obvious valuation challenges (Mann, 1997; Ibrahim, 2010; Menell, 2007). Fischer and de Rassenfosse (2011) report similar findings in a recent survey of lenders. Not surprisingly, however, direct evidence on lender expectations of the "saleability" of collateral assets is lacking. The most compelling evidence that lender decisions are swayed by conditions in the collateral resale market is based on physical assets in mature industries such as railroads (Benmelech, 2009) and commercial aircraft (Benmelech and Bergman, 2008, 2009; Gavazza 2011). As noted earlier, these studies find that thicker resale-market trading stimulates lending, particularly to firms with more redeployable (less firm-specific) assets. Whether similar effects arise in the more friction-filled patent market is far from clear.

As an asset class, intangibles are more difficult to value and trade than tangibles like commercial aircraft. Indeed, the intangibility of a firm's assets is a common proxy for low salvage value in the corporate finance literature. Anecdotal evidence nonetheless suggests that the

\footnotetext{
${ }^{7}$ A recent working paper by Basu, Metha and Winston Smith (2013) finds corroborating evidence for recently public companies, with more favorable syndicated loan terms post-IPO for companies with higher quality (more reputable) VCs.
} 
secondary market for buying and selling U.S. patents has flourished in the past few decades. ${ }^{8}$ In 1999, Intel Corporation launched its first patent purchasing program, formalizing the process by which it acquired patents either as standalone assets or through corporate takeovers (Chernesky, 2009). In 2003, Intellectual Ventures (IV), the largest patent “aggregator" organization formed to date, initiated an aggressive patent-buying program. By 2012, IV had spent over \$2 billion to amass one of the world's largest portfolios of 35,000 patents, primarily covering software, semiconductor and mobile computing inventions (Hagiu and Yoffie (2013). Hagiu and Yoffie (2013: 60) assert that, "[b]ecause of its size, Intellectual Ventures can single-handedly create liquidity in the market." The patent-market liquidity measure we utilize, described below, indirectly captures this effect by tracking the intensity of patent trading in different invention classes, including semiconductors and software (where IV is particularly active) and medical devices (where it is not).

To summarize, the incomplete contracting and financial intermediation literature yield three testable predictions in the venture-lending context. First, if increased liquidity in the secondary patent market is altering lender expectations of the salvage value, the likelihood that a startup will receive a loan should increase with thicker trading in the market for buying and selling patents, particularly when a startup's patents are more redeployable to alternative uses or users (less firmspecific). Second, the likelihood of lending should increase following a startup's first VC equity infusion, especially when reputable (skillful) VCs are involved. Finally, the likelihood of lending should depend on the ability of VC intermediaries to convey to lenders a credible commitment to monitor and support the risky project.

\section{Data Sources and Descriptive Findings}

How widespread is the use of debt in the financing of young innovative companies? More substantively, are there patent-market and/or VC-level mechanisms that facilitate contracting between entrepreneurs and lenders?

Answering these questions is challenging, both from a measurement and an identification perspective. As noted earlier, reliable startup-level data on venture loans is lacking. Novel to the field, our approach identifies loans to startups through patent collateral, thus revealing transactions difficult to glean from other sources. The approach nonetheless requires a focus on startups with one or more patent assets at risk of being used to secure a loan; otherwise, the presence or absence of a loan is unobservable. The remainder of this section describes our "patenting startup" sample

${ }^{8}$ Serrano (2010) reports that about 13.5 percent of all U.S. patents issued between 1983 and 2001 were traded at least once prior to expiration, with higher trade rates for small companies and more important (highly-cited) inventions. 
(Section 3.1), defines key variables and data sources (Section 3.2), and shows patterns revealed in the data (Section 3.3). We discuss identification challenges in Section 4.

\subsection{Sample Construction}

Our sample is drawn from the universe of U.S. venture capital-backed firms reported in Dow Jones' VentureSource (aka "VentureOne") database in three innovation-intensive sectors: software, semiconductor devices, and medical devices. Software and semiconductor device startups were sectors hard-hit by the technology bubble's collapse, while medical device startups were relatively shielded from its effect. Focusing on startups that eventually receive VC financing allows us to observe when each company first received a $\mathrm{VC}$ equity infusion and from whom they received such investment. We then select all startups founded from 1987, the first year of comprehensive reporting in VentureOne, through 1999. The latter cut-off captures the youngest cohort at risk of being affected by the market crash in early 2000 , and provides a common decade-

long window for tracking the startups' activities and outcomes. To better pinpoint when startups are independent and active, we supplement VentureOne data with information from Sand Hill Econometrics. As Hall and Woodward (2010) report, Sand Hill provides more accurate estimates on the timing of unsuccessful entrepreneurial outcomes, thus enabling us to better capture when startups disband and leave the risk pool for lending. Each company is tracked through 2008, our last year of reliable financing data, or until exit. The initial sample comprises 3,414 companies.

To identify startups with patents, we search the Delphion database for U.S. patents assigned to all current and former names listed for each startup as reported in VentureOne. Of the 3,414 startups, 1,519 receive at least one U.S. patent by 2008 or exit, averaging 9.5 patents per company. In the combined set of 14,514 patents, 51 percent are issued to 483 medical devices companies, 23 percent are issued to 197 semiconductor devices companies, and the remaining 26 percent are awarded to 839 software startups. The maximum portfolio size is 199 patents. The summary statistics and analyses below are based on this patenting-startup sample.

The main dataset is an unbalanced panel with 1,519 startups and 11,298 startup-calendar year observations, a subset of which is used in our difference-in-differences (DD) analysis. Startups are retained in the sample through 2008 or the year in which they went public, were acquired, or were disbanded. 


\subsection{Main Variables and Data Sources}

Our analysis requires measures of startup-level lending, patent-market activity, and VC investors. Appendix I summarizes our measures, and lists the sources used to compile them.

\section{Startup Receipt of Debt Financing}

Our outcome variable, $D E B T_{i t}$, indicates if one or more patents owned by a startup is used to secure a loan in a given year. To obtain information on patent security assignments, we extend the method introduced by Serrano (2010) and extract assignment records for each of the 14,514 patents from the USPTO Patent Assignment Database. ${ }^{9}$ We then identify, on a patent-by-patent basis, all instances where a patent "security interest" is assigned to a third party, i.e., a patent has been pledged as collateral ${ }^{10}$. For each record, we track the date of the transaction (execute date), the date the transaction was recorded (recorded date), the entity that assigned the security interest (assignor), the entity that received it (assignee), and the patent numbers involved in the transaction.

As expected, Silicon Valley Bank (SVB), an entity that specializes in banking services for startups, is the most common lien holder. SVB supplies loans to 35.2 percent of the 547 sample startups and an even larger share (42 percent) in the two IT-related sectors. In total, we identify 239 annual debt deals between Silicon Valley Bank and patenting startups. Of those, only eight (3 percent) are listed in the VentureOne database.

\section{Patent Market Liquidity}

Lender expectations of the salvage value of patents are unobservable. We therefore compute an indirect proxy, Patent Market Liquidity ${ }_{i t}$, to capture the annual likelihood that patents in a startup's portfolio will be traded. The measure and the premise behind it follows recent work by Gavazza (2011) on aircraft leasing: in decentralized markets, where buyers and sellers face fixed costs to search for the right trading partner, market thickness should facilitate reallocation to next-best use, thus increasing the salability of collateral assets. Despite the recent rise of aggregators like Intellectual Ventures, the market for buying and selling patents remains highly fragmented (Hagiu and Yoffie, 2013). The analogy therefore applies.

To compute the measure, we first identified a pool of potentially tradable patents relevant in the focal sector using lists of invention classes and subclasses compiled by USPTO examiners as reported in Appendix I. We then tally the annual count of U.S. patents awarded in each set of

\footnotetext{
${ }^{9}$ Serrano (2010) developed a methodology to distinguish the legal transfer of patent ownership from other administrative events, such as the pledge of patents as collateral, recorded at the USPTO Patent Assignments Database.

${ }^{10}$ Related terms on patent security agreements include "security interest", "security agreement", "collateral assignment", "collateral agreement", "lien", "mortgage," etc. Details are available upon request.
} 
classes and calendar year and, using patent sales data provided by RPX Corporation, the share involved in subsequent transactions. ${ }^{11}$ Consistent with Serrano (2010) and Galasso et al. (2013), patent sales are defined broadly to include sales of patents as standalone assets and transfers bundled through corporate acquisitions, a common route through which patent assets are transferred to new owners. ${ }^{12}$ Finally, Serrano (2010) shows that the vast majority of patent sales occur within eight years of issue and that the likelihood of a sale declines over the lifetime of a patent. We therefore restrict the pool of potentially tradable patents to those issued eight years prior to year $t$, and adjust the probability of sale based on the age profile of the startup's portfolio of

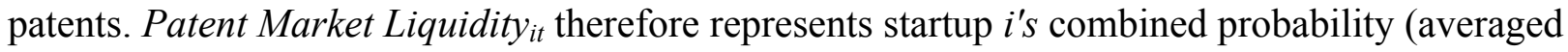
across patents in the portfolio of startup $i$ as of time $t$ ) that a patent issued in the prior eight-year window in the startup's sector will be traded in year $t$.

\section{Firm-Specificity of Patent Assets}

Discerning the firm-specificity (or redeployability) of patent assets is also challenging. Ideally, we would like a measure that tracks the extent to which patent collateral is likely to retain value if the company fails and the assets are sold to others. At one extreme, the assets could be perfectly "firm-specific" in the classic sense of Williamson (1988): rendered worthless if the company fails or the team disbands. This outcome could arise if the patent rights hold no value absent access to the underlying human capital. A startup's patents could also be highly "firm-specific" if they cover inventions that are nonviable on the market and/or hold no enforcement value in potential infringement lawsuits (e.g., see Galasso et al. 2010). At the other extreme, the patent rights could be highly redeployable (saleable) if the company fails. To illustrate, e-commerce patents owned by Commerce One sold for \$15.5 million at the startup's bankruptcy auction in 2005. Novell, an established software company, reportedly purchased the patents to ensure that they would not be used against it in future license negotiations or lawsuits (Markoff, 2005).

To capture the firm-specificity of patents assets, we compute the share of citations to the focal startup's patents in follow-on patents issued to the focal company versus to others (i.e., the proportion of follow-on references that are "self-cites"). More specifically, Firm-Specificity ${ }_{i t}$ is the

11 As per Serrano (2010), the RPX data are drawn from USPTO Assignment data and omit transaction types unrelated to patent sales, including the assignment of legal title from employees to their employers and security agreements with lenders. These data enable us to trace patent trading activity for U.S. patents over the full sample period.

12 To illustrate, Berman (2014) estimates that $\$ 7$ billion of the $\$ 12.5$ billion Google paid to acquire Motorola Mobility in 2011 was for the company's portfolio of 17,000 patents. Following the takeover, Google divested Motorola Mobility's core product unit (mobile handsets) but retained most of the patents transferred through the deal. 
annual share of citations that a startup's patents receive from other U.S. patents within three years of being granted that are self-citations. The three-year window provides a time-horizon likely to be relevant in startup lending. A higher self-cite share is assumed to correlate with higher "firmspecificity" levels and hence, more limited redeployability of the assets in the secondary market. The measure is similar in spirit to an internal-focus proxy used in Hoetker and Agarwal (2007)'s study of failed disk drive companies: the authors report a steeper decline in follow-on citations (invention use) following exits of companies with high self-citation shares in the pre-exit period. Marx et al. (2009) use a similar citations-based measure to gauge the firm-specificity of skills among employee-inventors.

\section{VC-Related Variables}

We examine the effects of VC involvement from several vantage points and with multiple measures. The first measure, Post $V C_{i t}$, is an indicator that switches from zero to one in the year that the startup receives its first VC equity infusion. First receipt of VC financing is determined based on close dates reported for VC rounds in VentureOne.

A second measure, Has Top-Tier $V C_{i t}$, captures whether and when a startup receives funds from a top-tier (highly reputable) VC, thus exploiting heterogeneity among VCs in reputational capital and skill. To identify top-tier VCs, investor names in VentureOne are matched to reputation scores computed by Lee, Pollock, and Jin (“LPJ” 2011). ${ }^{13}$ Computed annually for VCs active from 1990 through 2010, the LPJ scores range from 0, for fringe/new investors, to a maximum of 100, with a median value of 5.7 out of 100. Given high skew in VC reputation and skill levels (Hsu, 2004; Hochberg et al., 2014), Has Top-Tier $V C_{i t}$ is set to one if a startup has backing from one or more VCs in the top 5 percent of the LPJ score distribution by a given year. Use of a more stringent toppercentile threshold yields similar results. Of the 1,519 sample startups, 656 (43 percent) receive funds prior to exit from a VC with a top 5 percentile score while 863 (57 percent) do not. Kleiner Perkins and Sequoia Capital, venerable Silicon Valley investors, both fall in the top percentile of the distribution, with average annual scores of 77 and 62 respectively.

A third VC-related measure, Recent Fund ${ }_{i}$, is required for the DD analysis that exploits variation among VCs in fundraising cycles. As explained more fully in Section 4, Recent Fund ${ }_{i}$ is a

\footnotetext{
${ }^{13}$ Each VC's score is a composite measure based on years in operation, the average number of funds under management in the prior 5 years, the number of startups it has funded in the prior 5 years, the total amount of funds invested in the prior 5 years, and the number of companies taken public in the prior 5 years. The scores are posted at: http://www.timothypollock.com/vc reputation.htm. Not surprisingly, a VC's reputation score is slow moving in time. We therefore use a VC's score in 1990 to impute values in years (1987-1989) that pre-date the LPJ series.
} 
startup-level indicator set to one if the VC funds most recently raised by the startup's collection of investors are, on average, less than five years old as of early 2000, when the technology bubble collapsed. Although VentureOne reports the names of the VC firms investing in a startup and their rounds of participation, it does not track the individual funds from which those investors make investments. Most VC firms raise legally-separate, 10-12 year fund vehicles in an overlapping sequence, going out to raise funds 3-5 years after the prior fund raise. To map investors to funds, we obtain supplemental data from Private Equity Intelligence (PREQIN) that includes the vintage (close year) and size of funds raised by VC investors. According to PREQIN, $\$ 72.3$ billion in VC funds were raised worldwide between 1987 and 1999. Of that amount, $\$ 67.6$ billion (93 percent) matched to investors that have ownership stakes in sample startups. This statistic suggests that the investors represented in our study control the vast majority of $\mathrm{VC}$ funds in the industry.

\section{Other Measures}

Appendix I lists other control variables and data sources. Patent Portfolio Size (citationweighted $_{i t}$ is a time-varying measure of a startup's patent portfolio size in year $t$, normalized by the citations those patents receive within three years post-grant to capture the "importance" of those inventions. Funds Raised Last Equity Round ${ }_{i t}$ measures the millions of US dollars raised by the startup in its last equity round, which could affect the need for debt financing. Founding Year ${ }_{i}$ is the startup's year of establishment, thus capturing age/cohort effects. Sector $i j$ indicates whether the startup's primary sector is medical devices, semiconductor devices, or software. Finally, Time Period $_{t}$ allows for differences in entrepreneurial funding climates in the pre-boom (1987-1997), boom (1998-1999) and post-boom (2000-2008) periods. As is well-known, entrepreneurial capital was unusually plentiful in the late 1990s, a period often referred to as a "money chasing deals" era.

\subsection{Descriptive Findings}

Table 1 reveals that debt financing is quite common among the patent-producing, VC-backed startups in our sample. As shown in Table 1A, 36 percent of these patenting-startups secured loans pre-exit, with similar percentages across the three individual sectors. Of the 14,514 U.S. patents awarded to the startups by 2008 or prior to exit, more than 25 percent were involved in one or more security interest agreements. The percentage is highest for software startups, where almost onethird (32 percent) of the patents were used in lending. Panel B in Table 1 further shows that security agreements tend to cover most patents in a startup's portfolio: on average, the startups have liens on 92 percent of their patents by the year of the last reported loan transaction. As noted 
earlier, venture lenders typically take a blanket lien on all company assets when securing a loan, so this statistic is not surprising.

Table 2 compares observable characteristics of startups that do $(n=545)$ versus do not $(n=974)$ secure loans with patents. Although the mean age is similar across the groups, startups with loans tend to raise more equity capital than those without, have more (and more highly cited) patents on average, and are more frequently backed by top-tier investors. Nonetheless, the IPO rate for startups with loans is lower than that for those startups without (13 versus 21 percent), and a higher share of debt-financed companies ( 27 versus 20 percent) remained private by 2008 . A similar pattern holds for the subsample of startups founded in the late 1990s. Qualitatively, the pattern in Table 2 resonates with claims that venture lending is particularly useful when VCs seek to "extend the financial runway" of portfolio companies without resorting to new rounds of equity investing. As suggested in media reports (e.g., Tam, 2007), these loans may have enabled VCs to keep otherwise-promising companies afloat during a cold period in the venture capital market.

\section{Patent Market Liquidity and Venture Lending Activity}

Table 3 reports patent sales and the intensity of trading (Patent Market Liquidity) by technology sector and time period, alongside the annual debt rates for sample startups. Panel A shows that, between 1987 and 2008, 295,438 patents less than eight years old at the time of transaction were sold across the three sectors. Of those, 212,643 transactions (72 percent) were sold between 2000 and 2008. Patent sales have increased over time in all sectors, but the rise is especially noticeable in software, an effect partly due to disproportionate growth in the patenting of software inventions shown in prior studies (e.g., Cockburn and MacGarvie, 2011).

In Panel B of Table 3, we adjust for the pool of patents available for trading, thus normalizing sector-level differences in the annual supply of patents. The average Patent Market Liquidity value is 0.039 , which indicates that the combined sample probability that a patent issued within the last eight years will be sold in a given year is 3.9 percent. Estimates range from 5.1 percent in medical devices to 3.8 and 2.7 percent in the software and semiconductor devices sectors, respectively. ${ }^{14}$ Again, the upward time trend is most visible in software, where the intensity of patent-market trading increased by 75 percent (from 2.8 to 4.9 percent) from the pre- to post-boom periods. These patterns are consistent with claims of increased trading activity in secondary patent markets, particularly for software inventions (e.g., Hagiu and Yoffie, 2013).

${ }^{14}$ By comparison, Serrano (2010) reports an annual trade rate that ranges from 2.8 to 1.6 in the first eight years for patents granted to both U.S and foreign individuals from 1985-2000. The higher aggregate trade rate in our IT sectors reflects the focus on IT-related patents and the post-2000 period. 
Finally, Panel $\mathrm{C}$ of Table 3 shows the annual rate of lending to sample startups in equivalent time periods. In the frothy entrepreneurial and IPO climate of the late 1990s, industry insiders forecast that the venture lending market would collapse if VC funding became less plentiful (Gates, 1999). Indeed, the growth rate in lending between the pre-boom and boom period in Panel C is striking. The sample probability that a startup secured a loan in a given year (i.e., the average annual "debt rate") almost doubled, from 4.7 to 9.0 percent. Post-boom, however, the withinsample debt rate remained relatively stable, at 8.5 percent. This persistent reliance on debt financing could stem from multiple factors, including increased demand for non-equity sources of entrepreneurial financing when VC sources dwindled. Regardless, we find no evidence of market collapse following the "money-chasing-deals" era.

In unreported estimates (available upon request), we compute the correlation between the annual patent-market liquidity and annual startup debt rate in each sector. Not surprisingly, given evidence in Table 3, the correlations are positive and significant, ranging from 0.87 in software to 0.54 and 0.37 in medical devices and semiconductors respectively.

\section{VC Investors and Venture Lending Activity}

Are lending rates higher following a startup's first VC equity infusion and, conditional on receipt of such financing, for those with top-tier investors? The short answer is "yes." As shown in Figure 2, the average debt rate is much lower for startups before (versus after) first receipt of VC financing, at 3.0 versus 8.4 percent, a wide gap visible across the startup-age distribution.

Table 4 further distinguishes startups with top-tier VCs from those backed by lower-tier investors, and revisits time patterns. Conditional on receiving VC financing, the debt rate for startups with top-tier VCs is higher than that of startups backed solely by lower-tier investors, at 9.8 versus 7.5 percent. The average rates are comparable, however, except in the post-boom (200008) period. Interestingly, Table 4 also shows a steady climb over time in the debt rate for sample startups in periods before they receive VC financing, thus suggesting increased activity (albeit at much lower levels) in early phases of the entrepreneurial life cycle.

In summary, we find widespread use of debt in the financing of innovation-intensive startups, even in early stages of their development. The annual debt rate for sample companies strongly correlates with annual shifts in patent-market liquidity, particularly in the software sector. The debt rate is lowest for startups prior to first receipt of VC financing, and highest for those backed by toptier VCs. 


\section{Estimating the effects of patent markets and VC investors on startup lending}

Establishing whether patent trading activity and/or venture capitalists causally facilitate startup-level lending poses numerous identification challenges. Prior evidence suggests, for example, that entrepreneurs with prior IPO exits are more likely to secure external funds for their new ventures and from highly reputable VCs (Gompers et al., 2010). Such entrepreneurs also are likely to have better assets and financial resources unobservable to the econoetrician that could be used to guarantee a loan, thus increasing the likelihood of debt financing at their new companies. In this event, the presence of top-tier VC backing and of debt could be correlated, but not causally related. Similarly, VCs could simply select "higher quality" ventures that in turn are better candidates for lending. Below, we describe our approaches for dealing with these issues, report results, and conduct robustness checks with these and other identification challenges in mind.

\subsection{Baseline econometric model and results}

To start, we estimate the likelihood that a startup will obtain debt financing in a given year with a simple linear probability model:

$$
D_{E B T_{i t}}=\beta_{1} \text { Patent Market Liquidity }{ }_{i t}+\gamma_{1} \text { PostVC }_{i t}+\tau_{t}+X_{i t}+\theta_{i}+u_{i t}
$$

As explained earlier, $D E B T_{i t}$ indicates if startup $i$ receives a loan in year $t$, Patent Market Liquidity $_{i t}$ captures the intensity of patent-market trading in the startup's sector in year $t$ (adjusted by the annual age profile of the startup's patent portfolio), and Post $V C_{i t}$ switches to one in the year the startup first receives VC financing. The term $\tau_{\mathrm{t}}$ captures period differences in funding climate, while $X_{i t}$ represents time-varying startup characteristics that could affect the baseline probability of lending, including a company's age, prior equity funds raised, and patent portfolio sizes (citationadjusted to capture the importance of the inventions). $u_{i t}$ is the residual component.

The term $\theta_{i}$ in Equation (1) represents startup fixed effects. Importantly, including fixed effects at the startup level enables us to difference out permanent startup characteristics that might correlate with lending, such as the unobserved wealth of founders. More specifically, $\beta_{1}$ in Equation (1) captures the change in the probability that a startup obtains debt financing in a given year (i.e., its annual debt rate) due to shifts in patent-market trading not otherwise explained by the control variables and the fixed effects. Similarly, the coefficient $\gamma_{1}$ captures the added change in the predicted annual debt rate following first receipt of VC financing that is not explained by the controls.

Expanding Equation (1), we then add the Firm-Specificity proxy as well as an interaction between it and Patent Market Liquidity. The interaction term tests whether lending is less 
responsive to patent-market changes when a startup's patent assets are more firm-specific. Finally, we add the Has Top-Tier VC indicator to test whether the probability that a startup receives a loan is further heighted by equity infusions from investors that are especially reputable or skillful. Since PostVC is in Equation (1), Has Top-Tier VC acts as a step-function and captures whether the change in a startup's probability of receiving a loan post-VC financing is significantly higher when top-tier investors are involved, whether initially or in later rounds of financing.

The estimation sample is an unbalanced panel with 1,519 startups and 11,298 startup-calendar year observations. Table 5A shows summary statistics at the startup-year unit of observation. The statistics are in line with evidence reported in prior tables.

Table 6 reports OLS estimates of the likelihood that a startup receives a loan in a given year. Columns 1-3 focus on the two main variables in Equation (1), Patent Market Liquidity and PostVC and test the robustness of the estimates to different specifications. Columns 4 and 5 further probe the patent market effect, while Column 6 tests for any added effects due to top-tier investors.

The coefficients on PostVC and Patent Market Liquidity are positive and statistically significant both in Column 1 of Table 6, the parsimonious specification, and Column 2, which adds controls for the entrepreneurial funding climate, the startup's sector, and annual characteristics of each company (age, innovative output, and equity funds last raised). Column 3 adds startup fixed effects, thus identifying effects from within-startup variation. The PostVC and Patent Market Liquidity coefficients remain positive, significant, and comparable in magnitude. Replacing the period-wide controls with calendar year dummies yields similar results.

In combination, Columns 1-3 show that-even controlling for numerous time-varying factors and allowing for company-specific differences among startups (e.g., wealthy founders) to affect the likelihood of lending — annual debt rates are significantly higher after startups receive their first infusion of venture capital and when the market for buying and selling patents is more liquid.

If increased liquidity in the secondary market for patents shifts (unobservable) lender expectations of salvage value, we should find a disproportionate boost for startups with patent assets that are more redeployable to alternative uses or users (Williamson 1988; Benmelech and Bergman 2008, 2009). Put differently, lending should be less responsive to collateral-market conditions when patent assets are firm-specific.

The evidence in Columns 4 and 5 is consistent with this salvage-value interpretation. In Column 4, the coefficient on Firm-Specificity is negative and statistically significant, suggesting that lending rates are lower for startups with more firm-specific (less redeployable) patent assets. 
More importantly, in Column 5, the coefficient on the interaction, Firm-Specificity x Patent Market Liquidity, is negative and statistically significant: startups with firm-specific patent assets experience lower annual debt rates when patent market liquidity is high than startups with patent assets likely to retain more value if redeployed to alternative uses or uses. Interestingly, the main effect of Firm-Specificity is trivial in magnitude and statistically insignificant in Column 5. This result is also consistent with a salvage-value interpretation: absent liquidity in the patent market, the specificity (or redeployability) of patent assets should not affect the probability of startup lending.

To interpret the magnitude of the interaction effect in Column 5, we calculated the estimated effect of a one percentage point increase in patent-market liquidity from its mean value $(0.0448)$ at different points in the firm-specificity distribution - highly redeployable (bottom 10 percentile of the specificity distribution), average redeployability (mean value), and firm-specific (top 10 percentile) — with controls held at mean values. ${ }^{15}$ When redeployability is high, the one percentage point increase in patent-market liquidity predicts an increase in the annual debt rate by 0.0135 , that is 1.35 percentage points. When patent assets are firm-specific (redeployability is low), the magnitude of the effect is much smaller: an equivalent patent-market change increases the annual debt rate by only 0.004 , which is just 0.4 percentage points. At the mean firm-specificity value, the estimated effect is 0.116 , which is a 1.16 percentage point boost in the annual rate of startup lending. This marginal effect is large, corresponding to about 15 percent of the mean annual debt rate.

In combination, we interpret these results as evidence that increased trading in the secondary market for patent rights is shifting lender expectations of salvage value, expanding the financing opportunities of innovative companies.

Turning more closely to VC effects, Column 6 of Table 6 adds Has Top-Tier VC to the specification. The coefficient on Has Top-Tier VC is positive and significant, suggesting that the lending likelihood is heightened further by the presence of equity investment by highly reputable VCs. Based on coefficients in Column 6, the first receipt of VC financing (PostVC) increases the annual debt rate by 3.7 percentage points, from 4.6 to 8.3 percent, almost doubling the rate predicted at the mean. Backing from a top-tier investor, whether in an early or later round, increases the predicted debt rate by an additional 3.2 percentage points, a large added boost.

\footnotetext{
${ }^{15}$ For the bottom and top percentiles, estimates are based on the mean within-percentile specificity value.
} 
While interesting, our VC-related findings are prone to multiple interpretations. Consistent with financial intermediation theory, VCs could be serving an intermediary role in venture lending: by credibly committing to build and monitor portfolio companies through equity infusions, VCs could reduce financial frictions originating from information asymmetries between entrepreneurs and lenders. In this view, the relationship between the presence of VCs and startup lending is causal. Relatedly, being selected for funding by a VC, particularly one that is highly reputable or skillful, could alter lender expectations of the otherwise difficult-to-discern quality of the startup, similarly altering expectations of repayment in a causal manner.

Although qualitative accounts of the venture lending industry suggest that VCs serve an economically meaningful intermediary role, non-causal explanations for our VC findings are also plausible. To elaborate, recall the error term $u_{i t}$ in Equation (1). VC backing could correlate with this error term in either a negative or positive direction. A negative correlation could arise if a successful but cash-constrained startup suffers a negative shock to patent rights that reduces the tradability of those assets in the secondary market. Absent redeployable assets to pledge as collateral, equity arrangements could offer a more viable financing option, thus increasing the likelihood of VC financing while decreasing the likelihood of debt. Alternatively, and more troublesome given the directionality of our findings, a positive shock to the value of the technology underlying the startup could increase the company's growth opportunities in ways unobservable to us, increasing the likelihood of both debt and VC financing - a possibility that we turn to below.

\subsection{Difference-in-Differences Analysis}

In a separate and final set of analyses, we develop a novel method for identifying whether VCs serve an intermediary (causal) role in the market for venture lending. Our aim is to test an intermediary function of particular salience in incomplete contracting theory (Holmstrom and Tirole, 1997; Williamson, 1988): By credibly committing to lenders that they will exert future effort to build and refinance a portfolio company, do VCs facilitate the use of loans to finance risky entrepreneurial-firm projects? If the answer is yes, it implies that VCs add value as intermediaries in debt transactions beyond the ex ante screening of projects (whether via independent due diligence, which is likely, or from updates simultaneously known to lenders).

\section{Identification Strategy and Background}

To isolate a potential "VC credible commitment" effect, we exploit an unexpectedly severe and negative shock to the supply of capital to VC firms within our sample period - the collapse of the technology bubble in early 2000 - and differences in VC fundraising cycles at the time of that 
shock. As explained below, VCs that had not recently closed a new investment fund at the time of the shock should face more binding capital-constraints in the post-shock period than VCs with recently-closed funds for reasons unrelated to the quality of a given startup previously selected for funding. We use this plausibly exogenous source of variation among VCs to test a core prediction in the Holmstrom and Tirole (1997) model: following a negative capital-supply shock, financial intermediaries with binding constraints will find it difficult to convey to lenders that they will continue to support and monitor a portfolio company, thus reducing a startup's likelihood of receiving a loan.

To elaborate, the technology bubble's collapse is often pegged to March 2000, when Nasdaq shares plummeted from an unprecedented run-up in prices in the prior two years. Often referred to as the collapse of the "internet" or "dot.com" bubble, the steep fall in valuations had major ramifications across the IT sector. As one example, Cisco Corporation, a large computer networking company, lost more than 80 percent of its market capitalization in the one-year period following the shock. Not surprisingly, new VC investments in IT startups also suffered a precipitous decline. According to data from VentureOne, the amount of $\mathrm{VC}$ funds raised by software and semiconductor startups fell from \$6.6 billion in Q2 of 2000 to \$2.6 billion in Q2 of 2001 - a 60 percent one-year drop — and declined further, to $\$ 1.5$ billion, by Q2 of $2002 .{ }^{16}$ As Townsend (2012) and others document, the bubble's collapse significantly reduced the willingness of pension funds, wealthy individuals, and university endowments to commit funds to the VC asset class, particularly for IT-related investments, thus reducing the supply of institutional capital available for $\mathrm{VC}$ investing.

Although shockwaves were felt throughout the IT sector, VCs that had not yet closed a recent fund at the time of the crash should be particularly constrained, due to the "lumpy" process by which VCs raise funds. VC firms raise legally-separate individual funds, typically organized as Limited Partnerships, in overlapping sequences over time. At the start of each fund's life, the VC firm secures lump-sum commitments from institutional investors for investment over an agreedupon payback period. During the timeframe of our study, the standard lifespan of a VC fund was 10 years (Dow Jones, 2007). By the end of this period, the VC must realize returns through exits of

\footnotetext{
${ }^{16}$ In contrast, VC investments in the life sciences were relatively stable. Medical device and biopharmaceutical startups received \$1.3 billion in new VC funds in Q2 of 2000, a comparable \$1.29 billion in Q2 of 2001, and a slightly higher $\$ 1.6$ billion in Q2 of 2002. In medical devices alone, the amounts were $\$ 597$ million in Q2 of 2000, $\$ 500$ million in Q2 of 2001 and \$577 in Q2 of 2002. Estimates are quarterly amounts of VC dollars raised in each sector, as reported in VentureOne.
} 
portfolio companies by selling shares at IPO or to acquirers, and distribute the proceeds back to their institutional investors. Given this finite lifespan for a fund, the Limited Partnership fund agreements typically limit the "investment period" - the period during which new investments (i.e., investments in startup companies not already invested in by the fund) can be made - to 5 years (Dow Jones, 2007). As the investment period of an existing fund draws to a close, VCs begin fundraising for a follow-on fund, from which they will undertake future investments over the subsequent five year period. As a result, VC funds are typically spaced three to five years apart (Hochberg et al., 2014).

When an exogenous event — such as the collapse of the technology bubble in early 2000restricts the ability of the VC firm to close a new fund, the VC's ability to make new investments will be constrained: Investments in the existing fund will face additional competition for the remaining dollars, both from existing portfolio companies and from new investment opportunities, as the coffers cannot be replenished. A VC firm that was attempting to fundraise at the time of the bubble's collapse, or that needed to do so in its immediate aftermath, will have found it particularly difficult to source capital in the post-bubble period. As noted above, the VC fundraising cycle is largely determined by the timing of prior funds, and the timing and severity of the collapse was unexpected. We thus use heterogeneity in $\mathrm{VC}$ fundraising cycles at the time of the crash as a plausibly exogenous source of variation with which to identify the effect of VC credible commitment on startup lending.

\section{Supplemental Fund-Vintage Data, Estimation Sample, and Descriptive Evidence}

Implementing this methodology requires information about the vintage of funds managed by each startup's syndicate of VC investors as of early 2000. We therefore match investors in sample startups reported in VentureOne to supplemental data on VC funds reported in PREQIN. ${ }^{17}$ To start, we identify investors in a startup's most recent syndicate prior to the bubble's collapse, and compute the age of those investors' most recent VC funds as of the year 2000. Since the typical investment period in a VC fund is five years, we set RecentFund to one when the average age of the most recent funds within the syndicate is less than five years in early 2000. This approach allows the capital-constraints introduced by the market's collapse to be less (more) binding when a startup's investors have relatively recent (older) funds at the time of the crash. In robustness tests

${ }_{17}$ PREQIN reports information on all private equity funds raised worldwide, including but not limited to VC funds. Consistent with Hochberg et al. (2014), we classified "VC funds" if the fund focus in PREQIN was listed as startup, early-stage, development, late-stage, or expansion investments, venture capital (general), or balanced. 
discussed below, we experiment with alternative compositions of investors and fund-age thresholds.

Our main analysis focuses on startups that (a) compete in sectors most affected by the technology bubble's collapse (i.e., that are in IT-related sectors), (b) had VC financing prior to early 2000, thus allowing us to observe VC investors and the vintage of funds they manage, and (c) are at risk of receiving a loan over the entire 6-year period surrounding the crash, which allows us to test differential before-and-after shifts in startup-level lending. More specifically, the estimation sample comprises 119 semiconductor and software startups that were active as standalone companies between 1997 and 2002 and were backed by investors prior to 2000 whose VC funds are covered in PREQIN. Of these companies, eighty percent have syndicates of investors that have recently-raised funds in early 2000 (i.e., Recent Fund=1), while the remainder did not. The average age of new funds managed by syndicate partners for the startups was 2.62 (std. dev. 3.23) years at the time of the crash.

As previewed earlier, we find a dramatic and differential shift in startup lending patterns postshock that correlates with differences in VC fundraising cycles. In the three years prior to 2000, IT startups backed by investors with more recent VC funds at the time of the crash (i.e., with RecentFund $_{i}=1$ ) had an average annual debt rate of 10 percent. From 2000 through 2002, the annual debt rate for this group of startups increased slightly, to 13 percent. In sharp contrast, the average annual debt rate in the comparison group (i.e., IT startups with RecentFund $_{i}=0$ ) fell from 17 percent in the 1997-1999 period to 1.5 percent in the post-bubble period, a steep drop of 15.5 percent.

\section{Econometric Specification and Results}

To test the differential effect of VC fundraising cycles (credibility of $\mathrm{VC}$ commitment) on startup lending more formally, we use a difference-in-differences estimator:

$$
\text { Debt }_{i t}=\delta_{1} \text { After }_{i t}+\delta_{2} \text { RecentFund }_{i}+\delta_{3} \text { After }_{i t} * \text { RecentFund }_{i}+\delta_{4} W_{i t}+\theta_{i}+v_{i t}
$$

As above, $D E B T_{i t}$ indicates if startup $i$ receives a loan in year $t$, and RecentFund is an indicator set equal one when the most recent funds managed by startup $i$ 's investors are less than five years old on average in early 2000. After indicates startup-year observations in the three-year window following the bubble's collapse; the omitted category is a comparable three-year "pre-shock" period. The term $W_{i t}$ represents observable time-varying characteristics of startups that could affect the baseline probability of debt financing. Given evidence in Table 7, we add to prior controls the 
time-varying indicator (Has Top-Tier VC) of whether the startup has a top-tier VC by a given year. As before, startup fixed effects, represented by $\theta_{i}$, allow for time-invariant, company-specific, differences among startups to influence lending. In Equation (2), effects are therefore identified from within-startup changes in the annual debt rate during the six-year window.

The coefficient of interest, $\delta_{3}$, tests for differential changes in the annual debt rate for startups backed by investors with recent versus older funds when the bubble collapsed. Under the assumption that changes in the annual debt rate would be comparable for the startups had the bubble not collapsed, Equation (2) allows us to identify the causal effect of VC credible commitment to support the startup on the rate of lending. The identification assumption is that VC capital-constraints post-crash, as proxied by RecentFund, are largely exogenous to unobservables in the debt financing equation. Since the vintage year of a VC firm's most recent fund at the time of the crash is plausibly exogenous, this assumption seems reasonable.

Table 7 reports results of the DD estimator of changes (before versus after the technology bubble's collapse) in startup lending based on the fundraising cycles of VCs at the time of the crash. The unit of analysis is a startup-calendar year estimated in the six-year window surrounding the technology bubble's collapse, with 714 startup-year observations and 119 startups in our two IT-related sectors. Column 1 includes time-invariant startup controls only, while Column 2 uses startup fixed effects and time-varying covariates.

The difference-in-differences coefficient in Column 2, our preferred specification with fixedeffects with a full-set of controls, is 0.18 . This coefficient indicates that the annual debt rate of startups backed by VCs with relatively recent funds at the time of the crash (Recent Fund=1), relative to that of the startups backed by VCs with older funds (i.e., with more capital-constrained investors), increased by 18 percentage points during the post-shock period. Put differently, the dramatic shift in pre- versus post-shock lending reported earlier remains wide and is statistically significant even controlling for permanent and numerous time-varying characteristics of the startups.

Before interpreting these results, it is important to establish that the two groups of startups have comparable changes in annual debt rates prior to the "treatment". Figure 4 plots estimates from a more general empirical specification that allows the treatment effect to vary on an annual basis, with coefficients normalized to 1999 , the year prior to the shock. In years prior to the collapse, the estimated coefficients are statistically indistinguishable from zero, thus revealing parallel trends pre-treatment. Following the bubble's collapse, however, the estimated treatment effects are 
positive in all three years, which implies a differential shift in trajectories. The DD coefficient for the year of crash itself (which includes two months preceding the crash) is a positive 0.15 , but is not statistically significant ( $p$-value $=0.15$ ). In the first and second year immediately following the shock, however, the coefficients are positive 0.19 and 0.21 and are statistically significant (p-values 0.05 and 0.04 , respectively).

In combination, this evidence suggests a "flight-to-safety" among lenders in the wake of the technology bubble's collapse in early 2000. Following the collapse, lending continued apace and even increased slightly for startups backed by investors with relatively recently-raised funds, but fell sharply for startups with more capital-constrained investors. The large magnitude of the effect not only highlights the severity of the potential moral hazard problem between VCs and lenders but also how investors with relatively recently-raised funds can overcome this problem during a major capital illiquidity event, whereas the less capital-constrained cannot (Holmstrom and Tirole, 1997). Robustness checks and alternative explanations

In robustness and placebo tests described below, we experiment with alternative measures and estimation samples, and investigate factors unrelated to the credibility of $\mathrm{VC}$ commitment that could explain our findings.

First, we re-estimate the effects with alternative treatment assignment measures. Because the typical investment period for a $\mathrm{VC}$ fund is five years, our benchmark DD estimation assigned RecentFund $_{i}=1$ to startups when the mean age of the most recent funds managed by their investors as of the year 2000 was less than five years. In unreported results (available upon request), we experiment with alternative cutoffs near this benchmark case. When our preferred specification in Column 2 of Table 7 is replicated with a seven-year (versus five-year) treatment assignment for RecentFund $_{i}=1$, the DD coefficient remains significant at the 5-percent level but falls in magnitude to a positive 0.15 . This pattern is expected: the difference in post-shock lending should be smaller if we add more startups with (effectively) capital-constrained investors to the RecentFund $=1$ group. When we move in the opposite direction through use of a three-year assignment threshold (thus filtering out more startups from the RecentFund $=1$ group whose investors in all likelihood were unlikely to face binding constraints when sourcing capital in the post-shock period), the result is similar: The estimated DD coefficient is significant at the 5-percent level but smaller in magnitude, at 0.11 , as would be expected.

One concern is that "smarter" or better-connected CEOs could obtain debt financing for their startups regardless of the state of affairs in the VC industry and simultaneously better predict the 
timing and severity of the market collapse, leading them to seek investors with younger (investment-mode) funds. Although the mainstream view is that the timing and severity of the market's collapse was unexpected, this possibility could explain a positive correlation between startups with access to investors with recently raised funds and higher debt rates in the post-shock period.

To investigate this alternative "smart CEO" explanation for our findings, we reset the treatment assignment (RecentFund $=1$ ) based solely on the fund-raising state of the investors in the startup's first VC financing round. Typically, first-round investors continue to participate in later rounds to preserve ownership stakes and control, and should they decide not to reinvest, their actions are interpreted as a negative signal about the prospects of the startup, making it difficult for the startup to raise money. Thus, the capitalization of these initial investors should still matter for the startup's ability to raise debt after the technology market's collapse. At the same time, it is highly unlikely that even "smart" CEOs chose their early (versus later, more-recent)-round investors with an eye to capital shortages that they anticipate in an uncertainly-timed future post-bubble period. As shown in Column 3 of Table 7, the DD coefficient is a positive 0.13 when RecentFund is based on the vintage of funds managed by first-round investors, and remains statistically different than zero (pvalue $=0.03$ ). The confidence intervals of this coefficient and our baseline DD specification in Column 2 of Table 7 overlap, which is reassuring.

If our results are driven by the abilities of VCs to credibly commit to the continued financing of a portfolio company, we should expect a differential shift in lending only in the aftermath of a negative and severe capital-supply shock and in sectors most affected by the shock. In turn, in the absence of a shock to capital supply, differences in the fundraising cycles of VCs should not alter lender expectations of loan repayment. The final columns in Table 7 report placebo tests with this logic in mind.

Turning first to Column 4 of Table 7, we replicate the DD estimator for IT startups but in two non-crisis periods (1992-1997 and 2002-2006). ${ }^{18}$ Neither period witnessed a major shock to the supply of institutional capital available for VC investing. The panels, which are non-overlapping, are stacked to increase the number of observations available for the estimation. In total, 302 semiconductor and software startups were VC-backed and active in the two periods combined. As Column 4 shows, the DD coefficient in our preferred specification (fixed-effects with controls) is

${ }^{18}$ In light of the U.S. banking crisis, which began in the latter 2007 and worsened during 2008, we conservatively restrict the second window to a 5 -year period that ends in 2006. 
positive and small (0.028) in the non-crisis periods. Moreover, the coefficient is not statistically significant at conventional levels ( $\mathrm{p}$-value $=0.33$ ). We obtain similar results if the effects are estimated separately for each non-crisis period, albeit with smaller sample sizes.

Finally, Column 5 retains the six-year period surrounding the technology bubble's collapse, but tests effects for startups outside the IT sector, which were relatively shielded from the run-up and collapse. As shown earlier, new VC investments in IT startups plummeted in the wake of the bubble's collapse, while new investments in life science startups remained relatively stable. It is unlikely that the IT-driven shock imposed binding constraints in the sourcing of capital for life science startups, including (but not necessarily limited to) the medical device startups represented in our sample. Column 5 of Table 7 therefore replicates our preferred specification (fixed-effects with controls) using a placebo sample of medical device startups that were VC-backed by early 2000 and active in the six-year window surrounding the crash $(n=99)$. In contrast to our main findings, the DD coefficient is not significant at conventional levels ( $p$-value $=0.46)$ and is negative $(-0.048)$.

The placebo tests suggest that VC fundraising cycles shift lender expectations only when the capital constraints of the startup's VC investors are likely to be binding. Combined with the parallel pretreatment trend-lines shown in Figure 4, this evidence allays concerns that our main DD results are explained by unobserved time-varying characteristics of startups that could affect lending and investor matching in a non-causal manner: It is unclear why the effect would arise solely for IT startups, and specifically in the crisis period.

\section{Conclusion}

Despite the informational and contracting problems involved in the use of debt to finance risky entrepreneurial-firm projects, we document widespread lending to innovative companies in early stages of their development. Our approach, which maps startups to loans through patent security agreements, reveals startup-level lending activity that is difficult to glean from other sources. The empirical patterns we uncover suggest that, consistent with contract theory, collateral posting and intermediation by equity-owners are mechanisms that facilitate trading in friction-filled capital markets. Our empirical results provide the first systematic evidence that both mechanisms are at play in the market for venture lending.

Our patent-collateral findings may be considered surprising. Using sector-level indices on the annual intensity of patent trading, we show that the likelihood of startup lending increases when the secondary market for buying and selling patents grows more liquid, particularly for startups with 
patent assets that are more redeployable to other contexts (i.e., are less firm-specific). These findings resonate with classic predictions by Williamson (1988), Shleifer and Vishny (1992) and others: lender expectations of salvage value should affect the willingness to supply funds in the presence of contracting frictions. Although prior studies document this effect for tangible assets, such as airplanes and locomotives (Benmelech, 2009; Benmelech and Bergman, 2008, 2009; Gavazza, 2011), it is widely assumed that the market for patents is too illiquid to sway lender expectations. Our findings challenge this assumption, and suggest that patent assets and their exchange play a meaningful friction-reducing role in innovation financing.

Our findings suggest a natural stage for future research on the importance of patent market thickness for collateral-based financing. As is well known, intangible assets underpin the market value of modern U.S. corporations, many of which invest heavily in R\&D and patent-related activities. A natural question is whether the increased "salability" of patent assets affects the financing opportunities for this wider swath of companies, and if so, how the magnitude of the effect varies by sector. In the policy arena, the emergence of "patent assertion entities" and large "aggregators," such as Intellectual Ventures, has fueled concern that the acquisition and enforcement of patents by such organizations is imposing an ex post tax on innovation (U.S. White House, 2013; Hagiu and Yoffie, 2013). If these intermediaries increase the salability of patent assets, by increasing liquidity in the market, innovation-oriented companies could find it easier to borrow against their patents. This ex ante effect on innovation financing should be weighed, ideally with evidence from more companies and sectors, against the ex post distortions that may arise from patent trading and enforcement.

Our VC-related findings further suggest that the ability of informed investors to credibly commit to the future support and monitoring of risky projects is a key friction-reducing lever in financial intermediation theory (Holmstrom and Tirole, 1997; Rampini and Viswanathan, 2014). Identifying whether this causal relationship holds empirically is difficult: intermediaries and lenders may simultaneously see updates unobservable to researchers that increase the attractiveness of projects both for equity financing and lending. Our approach, which exploits differences in VC fundraising cycles at the time of a capital-supply shock, provides a useful lever for discerning this "credible commitment" effect of widespread theoretical interest in the field.

Following the collapse of the U.S. technology bubble in early 2000, and the withdrawal of institutional capital in its wake, we find that lending to startups with less capital-constrained investors continued apace and increased slightly. In sharp contrast, lending to startups backed by 
investors with more binding near-term constraints plummeted. Put differently, we show a dramatic "flight-to-safety" among lenders: they continued to finance startups backed by investors with less binding capital constraints following the collapse, but withdrew from otherwise-promising projects that may have needed the funds the most.

These findings suggest that VC credible commitment plays a vital role in the market for venture lending, in line with Holmstrom and Tirole (1997) and related arguments put forth by Williamson $(1983,1988)$. The magnitude of the effect also highlights the severity of the contracting challenges involved in lending to risky startups. As Harhoff (2009) and Hall and Lerner (2010) report, policy initiatives aim to stimulate entrepreneurial-firm innovation through debt channels of financing. Absent a well-developed infrastructure of venture capitalists and institutional investors, our evidence suggests that the economic effects of such initiatives will be muted.

In conclusion, this study provides novel evidence on the market for venture lending, a surprisingly active yet opaque arena for innovation financing. Our evidence challenges the widespread assumption that patent markets are too illiquid to sway lending activity. We further show that venture capitalists play an important intermediary role in the debt financing of risky companies and add value to deals above and beyond the ex ante screening of projects. 


\section{References}

Arora, A., A. Fosfuri, A. Gambardella. 2001. Markets for technology: The economics of innovation and corporate strategy. Cambridge, MA: MIT Press.

Benmelech, E. 2009. Asset saleability and debt maturity: Evidence from nineteenth-century American railroads. Rev. of Financial Studies 22(4): 1545-1584.

Benmelech, E. N.K. Bergman. 2008. Liquidation values and the credibility of financial contract renegotiation: Evidence from U.S. airlines. Quarterly J. Econom. 123(4): 1635-1677.

Benmelech, E., N.K. Bergman. 2009. Collateral pricing. J. Financial Econom. 91(3): 339-360.

Berman, B. 2014. The intangible investor. Intellectual Asset Magazine. 65 (May/June): 33.

Basu, S., M.N. Mehta, S. Winston Smith. 2013. Venture capital reputation and loan contracts. Working paper.

Brassell, M., K. King. 2013. Banking on IP? The role of intellectual property and intangible assets in facilitating business finance: Final Report. Newport, UK: UK Intellectual Property Office.

Cerqueiro, G., D. Hegde, M.F Penas, R. Seamans. 2014. Debtor rights, credit supply, and innovation. TILEC Discussion Paper No. 2014-011, posted at http://papers.ssrn.com/sol3/papers.cfm?abstract id=2246982

Chava, S., A. Oettl, A. Subramanian, K.V. Subramanian. 2013. Banking deregulation and innovation. J. Financial Econom. 109(3): 759-774.

Chemmanur, T.J., K. Krishnan, D.K. Nandy. 2011. How does venture capital financing improve efficiency in private firms? A look beneath the surface. Rev. Financial Studies. 24(12): 40374090.

Cockburn, I.M., M. MacGarvie. 2011. Entry and patenting in the software industry. Management Sci. 57(5): 915-933.

De Bettignies, J.E. 2008. Financing the entrepreneurial venture. Management Sci. 54(1): 151-166.

De Meza, D., D.C. Webb. 1987. Too much investment: A problem of asymmetric information, Quarterly J. Econom. 102(2): 281-292.

Dow Jones. 2007. Private equity partnership terms and conditions. New York: Dow Jones \& Company.

Fischer, T., G. de Rassenfosse. 2011. Debt financing of high-growth startups: The venture lending business model. DRUID working paper 11-04.

Galasso, A., M. Schankerman, C.J. Serrano. 2013. Trading and enforcing patent rights. Rand J. of Econom. 44(2): 275-312.

Gates, S.T. 1999. Debt financing for young private companies is a trend that can't last. Red Herring. Jan: 98.

Gavazza, A. 2011. The role of trading frictions in real asset markets. Amer. Econom. Rev. 101(4): 1106-1143.

Gordon, R. 2013. Venture debt: a capital idea for startups. Kauffman Fellows Press. Available at: http://kauffmanfellows.org/journal_posts/venture-debt-a-capital-idea-for-startups/

Graham, S.J.H., S. Vishnubhakat. 2013. Of smart phone wars and software patents. J. Econom. Persp. 27(1): 67-86.

Gompers, P.A., A. Kovner, J. Lerner, D. Scharfstein. 2010. Performance persistence in entrepreneurship. J. Financial Econom. 96(1): 18-32.

Haemmerli, A. 1996. Insecurity interests: where intellectual property and commercial law collide. Columbia Law Rev. 96(7): 1645-1753.

Hagiu, A., D.B. Yoffie. 2013. The new patent intermediaries: platforms, defensive aggregators, and super-aggregators. J. Econom. Persp. 27(1): 45-66. 
Hall, B.H., J. Lerner. 2010. The financing of R\&D and innovation. In BH Hall and N Rosenberg (eds.), Elsevier Handbook of the Economics of Innovation.

Hall, B.H., R.H. Ziedonis. 2001. The patent paradox revisited: an empirical study of patenting in the U.S. semiconductor industry. Rand J. Econom. 32(1): 101-128.

Hall, R.E., S.E. Woodward. 2010. The burden of the nondiversifiable risk of entrepreneurship. Amer. Econom. Rev. 100(3): 1163-1194.

Harhoff, D. 2009. The role of patents and licenses in securing external finance for innovation. European Investment Bank (EIB) Papers. 14(2):

Hardymon, F., J. Lerner, A. Leamon. 2005. Gold Hill Venture Lending. HBS case \#9-804-083.

Hegde, D., J. Tumlinson. 2014. Does social proximity enhance business partnerships? Theory and evidence from ethnicity's role in US venture capital. Management Sci., forthcoming.

Hellmann, T., M. Puri. 2002. Venture capital and the professionalization of startup firms: empirical evidence. J. Finance 57(1): 169-197.

Hochberg, Y., A.P. Ljungqvist, Y. Lu. 2007. Whom you know matters: venture capital networks and investment performance. J. Finance 62(1): 251-301.

Hochberg, Y., A.P. Ljungqvist, A. Vissing-Jorgensen. 2014. Information holdup and performance persistence in venture capital. Rev. Financial Studies. 27(1): 102-152.

Hoetker, G., R. Agarwal. 2007. Death hurts, but it isn't fatal: the post-exit diffusion of knowledge created by innovative companies. Academy of Management J. 50(2): 446-467.

Holmstrom, B., J. Tirole. 1997. Financial intermediation, loanable funds, and the real sector. Quarterly J. Econom. 112(3): 663-691.

Hsu, D.H. 2004. What do entrepreneurs pay for venture capital affiliation? J. Finance. 59(4): 18051844.

Hsu, D.H. 2006. Venture capitalists and cooperative start-up commercialization strategy. Management Sci. 52(2): 204-219.

Johnson, H., R. Stulz. 1985. An analysis of secured debt. J. Financial Econom. 14(4): 501-522.

Ibrahim, D.M. 2010. Debt as venture capital. Univ. Illinois Law Rev. 2010(4): 1169-1210.

Kerr, W., R. Nanda. 2009. Democratizing entry: banking deregulations, financing constraints, and entrepreneurship. J. Financial Econom. 94(1): 124-149.

Lamoreaux, N.R., K.L. Sokoloff. 1999. Inventors, firms, and the market for technology in the late nineteenth and early twentieth centuries. In N.R. Lamoreaux, D.M.G. Raff, and P. Temins (eds). Learning by Doing in Markets, Firms, and Countries. Chicago IL: Chicago University Press, pp. 19-57.

Lee, P.M, T.G. Pollock, K. Jin. 2011. The contingent value of venture capitalist reputation. Strategic Organization. 9(1): 33-69.

Leland, H.E., D.H. Pyle. 1977. Information asymmetries, financial structure, and financial intermediation. J. Finance. 32(2): 371-387.

Lerner, J. 1995. Venture capitalists and the oversight of privately-held firms. J. Finance. 50(1): 301-318.

Levin, S. 2008. Venture debt: device financing lifeline or anchor? In Vivo, March: 1-8.

Ljungqvist A., M. Richardson. 2003. The cash flow, return, and risk characteristics of private equity. NBER working paper \#9454.

Mann, R.J. 1997. The role of secured credit in small-business lending. Georgetown Law J. 86(1): 144.

Mann, R.J. 1999. Secured credit and software financing. Cornell Law Rev. 85(1): 134-188.

Mann, W.M. 2014. Creditor rights and innovation: Evidence from patent collateral. Working paper. http://fnce.wharton.upenn.edu/profile/1033/ 
Markoff, J. 2005. Buyer of e-commerce patents turns out to be Novell. New York Times, 02 May: B1.

Marx, M., Strumsky D., Fleming, L. 2009. Mobility, skills, and the Michigan non-compete experiment. Management Sci. 55(6): 875-889.

Menell, P.S. 2007. Bankruptcy treatment of intellectual property assets: An economic analysis. Berkeley Techn. Law J. 22: 733-823.

Nanda, R., Rhodes-Kropf. 2014. Financing Risk and Innovation. Harvard Business School Working Paper, No. 11-013.

Puri, M., R. Zarutskie. 2012. On the life cycle dynamics of venture-capital and non-venture-capitalfinanced firms. J. Finance. 67(6): 2247-93.

Rampini, A.A., S. Viswanathan. 2014. Financial Intermediary Capital. Working paper. https://faculty.fuqua.duke.edu/ rampini/papers/intermediarycapital.pdf

Robb, A., D. Robinson. 2014. The capital structure decisions of new firms. Rev. Financial Studies. 67(6): 2247-2293.

Shleifer, A., R.W. Vishny. 1992. Liquidation values and debt capacity: A market equilibrium approach. Journal of Finance 47(4): 1343-1366.

Serrano, C. 2010. The dynamics of the transfer and renewal of patents. RAND J. Econom. 41(4): 686-708.

Tam, P.W. 2007. Venture funding twist: start-ups increasingly take on debt to keep businesses chugging along. Wall Street J. 14 Feb C1.

Townsend, R. 2012. Propagation of financial shocks: The case of venture capital. Working paper. SSRN: http://ssrn.com/abstract $=2021301$

Ueda, M. 2004. Banks versus venture capital: Project evaluation, screening, and expropriation. $J$. Finance. 59(2): 601-621.

U.S. White House. 2013. Patent assertion and U.S. innovation. Executive Office of the President. Washington D.C.: U.S. White House.

Williamson, O.E. 1983. Credible commitments: Using hostages to support exchange. Amer. Econom. Rev. 73(4): 519-540.

Williamson, O.E. 1988. Corporate finance and corporate governance. J. Finance. 43(3): 567-591. 
TABLE 1. Patent Security Interests

\begin{tabular}{|c|c|c|c|c|}
\hline \multicolumn{5}{|l|}{ A. Startup-Level Analysis } \\
\hline & \multirow[b]{2}{*}{ All } & \multicolumn{3}{|c|}{ Sectors } \\
\hline & & $\begin{array}{l}\text { Medical } \\
\text { Devices } \\
\end{array}$ & $\begin{array}{c}\text { Semiconductor } \\
\text { Devices } \\
\end{array}$ & Software \\
\hline Share of startups with loans secured by patents & 0.36 & 0.36 & 0.38 & 0.35 \\
\hline Number of startups & 1,519 & 483 & 197 & 839 \\
\hline
\end{tabular}

\section{B. Patent-Level Analysis}

\begin{tabular}{lcccc}
\hline & All & $\begin{array}{c}\text { Medical } \\
\text { Devices }\end{array}$ & $\begin{array}{c}\text { Semiconductor } \\
\text { Devices }\end{array}$ & Software \\
\cline { 2 - 5 } & & & 0.26 & 0.32 \\
$\begin{array}{l}\text { Share of all patents awarded to sample startups by } \\
2008 \text { or exit used to secure a loan }\end{array}$ & 0.27 & 0.26 & & 0.89 \\
$\begin{array}{l}\text { Share of patent portfolio used as collateral by last } \\
\text { transaction year (average for startups with loans) }\end{array}$ & 0.92 & 0.88 & & 0.94 \\
$\begin{array}{l}\text { Total \# U.S. patents awarded to sample startups by } \\
2008 \text { or exit year }\end{array}$ & 14,514 & 7,435 & 3,288 & 3,791 \\
\hline
\end{tabular}


TABLE 2. Summary Statistics: Patenting Startups with vs. without Patent-backed Debt

\begin{tabular}{lccc}
\hline \hline & $\begin{array}{c}\text { All Sample Startups With } \\
\text { Patents }\end{array}$ & $\begin{array}{c}\text { Subsample with Patent- } \\
\text { backed Debt }\end{array}$ & $\begin{array}{c}\text { Subsample without Patent- } \\
\text { backed Debt }\end{array}$ \\
\cline { 2 - 4 } & & & 0.45 \\
Backed by Top-Tier VC (\%) & 0.42 & 33.3 & 0.40 \\
Total VC Funds raised (\$ million) & 27.1 & 11.7 & 23.7 \\
Patent Portfolio Size & 9.55 & 73.6 & 8.3 \\
Patent Portfolio Size, citation weighted & 62.17 & 1994.8 & 55.8 \\
Founding Year & 1994.9 & & 1995.0 \\
Startup status as of 2008 (\%) & & & 0.13 \\
$\quad$ IPO & 0.18 & 0.21 & 0.21 \\
$\quad$ Disbanded (Failed) & 0.21 & 0.27 & 0.20 \\
$\quad$ Still Private & 0.22 & 0.40 & 0.20 \\
$\quad$ Acquired & 0.39 & 545 & 0.39 \\
Number of Startups & & & 974 \\
\end{tabular}

Note: The sample includes VC-backed startups in three sectors (medical devices, semiconductor devices, and software) awarded at least one U.S. patent by 2008 or exit. Startups with (without) patent-backed debt have (do not have) at least 1 patent-backed security agreement recorded at the PTO through 2008 or exit. 
TABLE 3. Patent Sales, Patent-Market Liquidity, and the Annual Startup Debt Rate Across Time and Technology Sectors

\begin{tabular}{lcccc}
\hline \hline & & $\begin{array}{c}\text { Pre-boom } \\
\text { Bll years }\end{array}$ & $\begin{array}{c}\text { Boom years } \\
\text { A. Patent Sales }\end{array}$ & $\begin{array}{c}\text { Post-boom } \\
\text { Medical devices }\end{array}$ \\
\hline Semiconductors & 46,632 & 11,994 & 5,109 & 29,529 \\
Software & 28,778 & 3,553 & 2,451 & 22,774 \\
All three sectors & 220,028 & 39,359 & 20,329 & 160,340 \\
B. Patent Market Liquidity & & & & \\
\hline Medical devices & 295,438 & 54,906 & 27,889 & 212,643 \\
Semiconductors & 0.051 & 0.043 & 0.060 & 0.060 \\
Software & 0.027 & 0.018 & 0.036 & 0.036 \\
All three sectors & 0.038 & 0.028 & 0.047 & 0.049 \\
C. Annual Startup Debt Rate (within-sample) & & 0.048 \\
\hline Medical devices & 0.039 & 0.030 & 0.048 & \\
Semiconductors & 0.069 & 0.052 & 0.069 & 0.080 \\
Software & 0.076 & 0.041 & 0.082 & 0.091 \\
All three sectors & 0.080 & 0.043 & 0.105 & 0.085 \\
\hline
\end{tabular}

NOTE: In Panel A, "Patent sales" is a running stock of U.S. patents less than eight years old that were sold by year $t$. Sector-level tallies are based on USPTO invention class-subclass lists. In Panel B, "Patent Market Liquidity" adjusts the sales (transactions) counts by the pool of patents available for trading, defined as all U.S. patents issued in the same set of PTO class-subclasses for the sector in the prior eight years. In Panel C, "Annual startup debt rate" is the sample probability that a startup secures patent-backed lending in a given year. See Appendix I for data sources. 
TABLE 4. Startup Debt Rate and VC backing: Startups with vs. without Top-Tier VC

\begin{tabular}{lcccc}
\hline \hline & \multicolumn{1}{c}{$\begin{array}{c}\text { Not Yet VC- } \\
\text { Backed }\end{array}$} & $\begin{array}{c}\text { VC backed: } \\
\text { Has Top-Tier } \\
\text { VC }\end{array}$ & $\begin{array}{c}\text { VC backed: } \\
\text { Lacks Top- } \\
\text { Tier VC }\end{array}$ & $\begin{array}{c}\text { T-test: Has vs } \\
\text { Lacks Top-tier VC } \\
\text { (p-value) }\end{array}$ \\
\cline { 2 - 5 } Time periods & & & & \\
\hline Pre-boom (1987-97) & 0.022 & 0.062 & 0.062 & 0.99 \\
Boom years (1998-99) & 0.041 & 0.113 & 0.098 & 0.39 \\
Post-boom (2000-08) & 0.045 & 0.106 & 0.075 & 0.00 \\
\hline All years & 0.030 & 0.098 & 0.075 & 0.00 \\
\hline
\end{tabular}

Note: Debt rate is the sample probability that a startup secures a loan in a given year. Has Top-Tier $\mathrm{VC}$ is equal to 1 if the startup has already secured $\mathrm{VC}$ financing from at least one investor with reputation score in the top 5 percentile of the annual distribution of scores reported in LPJ2011. 
TABLE 5. Summary Statistics at the Startup-Calendar Year Unit of Analysis

\begin{tabular}{|c|c|c|c|c|c|c|}
\hline & Mean & S.D. & Min & Max & \# Startups & $\begin{array}{l}\text { \# Startup- } \\
\text { Year Obs. }\end{array}$ \\
\hline \multicolumn{7}{|c|}{ A. Main Analysis (all three sectors, years $=1987-2008$ ) } \\
\hline Debt & 0.08 & 0.26 & 0 & 1 & 1,519 & 11,298 \\
\hline Post VC & 0.84 & 0.36 & 0 & 1 & 1,519 & 11,298 \\
\hline Has Top-Tier VC & 0.32 & 0.47 & 0 & 1 & 1,519 & 11,298 \\
\hline Patent Market Liquidity & 0.045 & 0.017 & 0 & 0.085 & 1,519 & 11,298 \\
\hline Firm-Specificity of Patent Assets & 0.092 & 0.157 & 0 & 1 & 1,458 & 10,854 \\
\hline Patent Portfolio Size (Citation Weighted) & 47.57 & 133.91 & 0 & 3,639 & 1,519 & 11,298 \\
\hline Patent Portfolio Size & 7.29 & 12.24 & 0 & 199 & 1,519 & 11,298 \\
\hline Funds Raised Last Equity Round (million \$) & 8.82 & 11.13 & 0 & 122 & 1,519 & 11,298 \\
\hline Founding Year & 1994.81 & 3.55 & 1987 & 1999 & 1,519 & 11,298 \\
\hline Primary sector $=$ software & 0.52 & 0.50 & 0 & 1 & 1,519 & 11,298 \\
\hline Primary sector $=$ semiconductors & 0.13 & 0.34 & 0 & 1 & 1,519 & 11,298 \\
\hline Primary sector $=$ medical devices & 0.35 & 0.48 & 0 & 1 & 1,519 & 11,298 \\
\hline Pre-boom period (1987-1997) & 0.25 & 0.43 & 0 & 1 & 1,519 & 11,298 \\
\hline Boom period (1998-1999) & 0.15 & 0.36 & 0 & 1 & 1,519 & 11,298 \\
\hline Post-boom period (2000-2008) & 0.60 & 0.49 & 0 & 1 & 1,519 & 11,298 \\
\hline \multicolumn{7}{|c|}{ B. Difference-in-Differences Analysis (semi and software sectors only; years=1997-2002) } \\
\hline Debt & 0.11 & 0.32 & 0 & 1 & 119 & 714 \\
\hline Post VC & 0.88 & 0.32 & 0 & 1 & 119 & 714 \\
\hline Has Top-Tier VC & 0.39 & 0.49 & 0 & 1 & 119 & 714 \\
\hline Patent Market Liquidity & 0.044 & 0.016 & 0 & 0.070 & 119 & 714 \\
\hline Patent Portfolio Size (Citation Weighted) & 45.72 & 77.55 & 0 & 648 & 119 & 714 \\
\hline Patent Portfolio Size & 7.52 & 11.33 & 1 & 86 & 119 & 714 \\
\hline Funds Raised Last Equity Round (million \$) & 11.01 & 11.80 & 0 & 59.5 & 119 & 714 \\
\hline Founding Year & 1994.16 & 2.94 & 1987 & 1999 & 119 & 714 \\
\hline Primary sector $=$ software & 0.75 & 0.43 & 0 & 1 & 119 & 714 \\
\hline Primary sector $=$ semiconductors & 0.25 & 0.43 & 0 & 1 & 119 & 714 \\
\hline Recent Fund & 0.81 & 0.40 & 0 & 1 & 119 & 714 \\
\hline
\end{tabular}

NOTE: Appendix I reports variable definitions and data sources. 
TABLE 6. Patent Market Liquidity, VC Investors, and the Likelihood of Startup Debt Financing

\section{Estimation Method}

Dependent Variable

Post VC

Patent Market Liquidity

Firm Specificity

Firm Specificity * Patent Market Liquidity

Has Top-Tier VC

Startup Fixed Effects

Patent Portfolio Size (citation-weighted)

Funds Raised Last Equity Round

Period Fixed Effects

Founding Year Fixed Effects

Sector Fixed Effects

No. of Startups

Observations

$\begin{array}{cccccc}1 & 2 & 3 & 4 & 5 & 6 \\ \text { OLS } & \text { OLS } & \text { OLS } & \text { OLS } & \text { OLS } & \text { OLS } \\ \text { Debt } & \text { Debt } & \text { Debt } & \text { Debt } & \text { Debt } & \text { Debt }\end{array}$

$\begin{array}{cccccc}0.043 * * * & 0.037 * * * & 0.040 * * * & 0.042 * * * & 0.042 * * * & 0.037 * * * \\ (0.006) & (0.007) & (0.009) & (0.010) & (0.010) & (0.010) \\ 0.912 * * * & 1.264 * * * & 1.216 * * * & 1.218 * * * & 1.349 * * * & 1.327 * * * \\ (0.137) & (0.163) & (0.200) & (0.209) & (0.209) & (0.225) \\ & & & -0.066 * * & 0.008 & 0.005 \\ & & (0.031) & (0.044) & (0.043) \\ & & & -2.013 * * & -1.969 * * \\ & & & (0.940) & (0.937) \\ & & & & 0.032 * * \\ & & & & (0.015)\end{array}$

$\begin{array}{lccccc}\text { NO } & \text { NO } & \text { YES } & \text { YES } & \text { YES } & \text { YES } \\ \text { NO } & \text { YES } & \text { YES } & \text { YES } & \text { YES } & \text { YES } \\ \text { NO } & \text { YES } & \text { YES } & \text { YES } & \text { YES } & \text { YES } \\ \text { NO } & \text { YES } & \text { YES } & \text { YES } & \text { YES } & \text { YES } \\ \text { NO } & \text { YES } & \text { NO } & \text { NO } & \text { NO } & \text { NO } \\ \text { NO } & \text { YES } & \text { NO } & \text { NO } & \text { NO } & \text { NO } \\ & & & & & \\ 1,519 & 1,519 & 1,519 & 1,458 & 1,458 & 1,458 \\ 11,298 & 11,298 & 11,298 & 10,854 & 10,854 & 10,854\end{array}$

Note: The unit of analysis is a startup-calendar year, with an unbalanced panel. Debt $=1$ if the firm is involved in at least one security interest agreement in a calendar year. Robust standard errors, clustered at the startup level, are reported in parenthesis. Statistical significance: $* 10$ percent, $* * 5$ percent, $* * * 1$ percent. 
TABLE 7. Difference-in-Differences (DD) of Startup Debt Rate Before and After the Technology Bubble's Collapse in Early 2000: Startups backed by Investors with Recent (versus Older) Funds at the Time of the Crash

\begin{tabular}{|c|c|c|c|c|c|}
\hline \multirow{4}{*}{$\begin{array}{l}\text { Estimation Method } \\
\text { Dependent Variable }\end{array}$} & \multicolumn{3}{|c|}{ Main Results } & \multicolumn{2}{|c|}{ Falsification Tests } \\
\hline & 1 & 2 & 3 & 4 & 5 \\
\hline & DD & DD & DD & DD & DD \\
\hline & Debt & Debt & Debt & Debt & Debt \\
\hline DD coefficient & $\begin{array}{c}0.187 * * * \\
(0.056)\end{array}$ & $\begin{array}{c}0.181^{* * *} \\
(0.055)\end{array}$ & $\begin{array}{c}0.128^{* *} \\
(0.063)\end{array}$ & $\begin{array}{c}0.028 \\
(0.030)\end{array}$ & $\begin{array}{l}-0.048 \\
(0.060)\end{array}$ \\
\hline Startup Fixed Effects & NO & YES & YES & YES & YES \\
\hline Has Top-Tier VC & NO & YES & YES & YES & YES \\
\hline Funds Raised Last Equity Round & NO & YES & YES & YES & YES \\
\hline Patent Portfolio Size (citation-weighted) & NO & YES & YES & YES & YES \\
\hline Founding Year Fixed Effects & YES & NO & NO & $\mathrm{NO}$ & NO \\
\hline Sector Fixed Effects & YES & NO & NO & NO & NO \\
\hline Event Year & 2000 & 2000 & 2000 & $\begin{array}{c}\text { placebo years } \\
(1995,2005)\end{array}$ & 2000 \\
\hline $\begin{array}{l}\text { Recent Fund is computed with data of } \\
\text { the investors that participated in the... }\end{array}$ & $\begin{array}{l}\text { Last round of VC } \\
\text { financing pre- } 2000\end{array}$ & $\begin{array}{l}\text { Last round of VC } \\
\text { financing pre- } 2000\end{array}$ & $\begin{array}{l}\text { First round of } \mathrm{VC} \\
\text { financing }\end{array}$ & $\begin{array}{l}\text { Last round of VC financing pre- } \\
\text { placebo year }\end{array}$ & $\begin{array}{l}\text { Last round of VC } \\
\text { financing pre-2000 }\end{array}$ \\
\hline Sample & $\begin{array}{c}\text { software and semi. } \\
\text { startups active } 1997-2002 \\
\text { and VC-backed by } 2000\end{array}$ & $\begin{array}{l}\text { software and semi. } \\
\text { startups active } 1997-2002 \\
\text { and VC-backed by } 2000\end{array}$ & $\begin{array}{c}\text { software and semi. } \\
\text { startups active } 1997-2002 \\
\text { and VC-backed by } 2000\end{array}$ & $\begin{array}{l}\text { software } \& \text { semi. startups } \\
\text { active } 1992-97(2002-06) \text { and } \\
\text { VC-backed by placebo year }\end{array}$ & $\begin{array}{l}\text { medical device startups } \\
\text { active } 1997-2002 \text { and VC- } \\
\text { backed by } 2000\end{array}$ \\
\hline No. of Startups & 119 & 119 & 100 & 302 & 99 \\
\hline Observations & 714 & 714 & 600 & 1,572 & 594 \\
\hline
\end{tabular}


Figure 1. Venture Lending as a Way to "Extend the Financial Runway" of a Startup

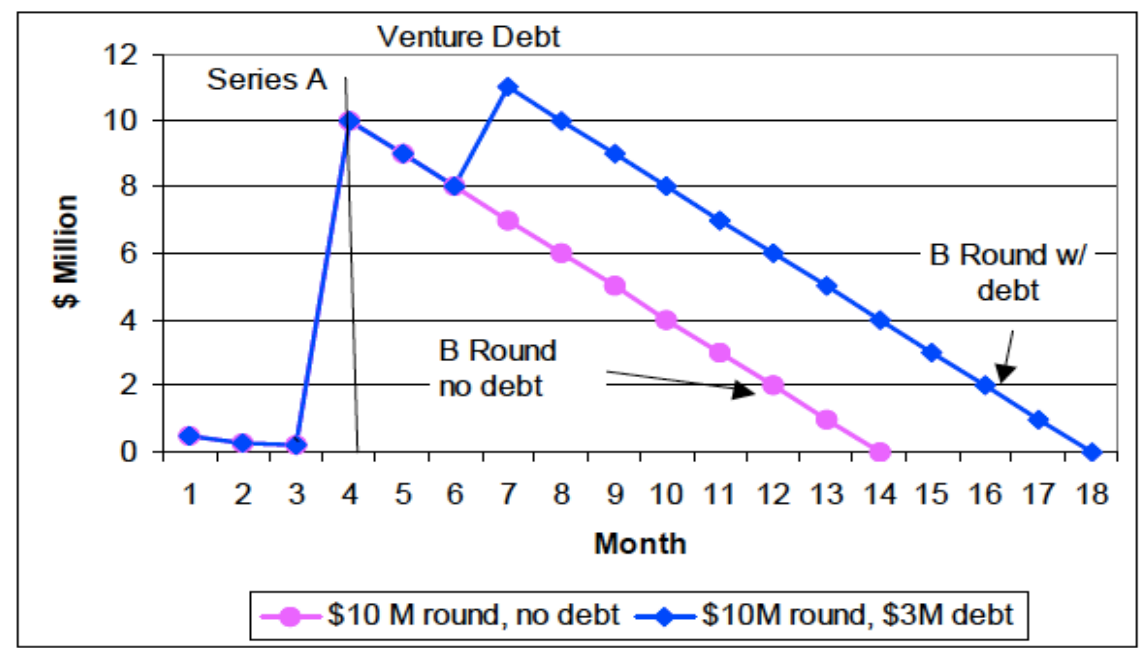

Source: Hardymon, Lerner, and Leamon (2005).

Figure 2. Average annual debt rate before and after first VC equity infusion: overall and by age thresholds

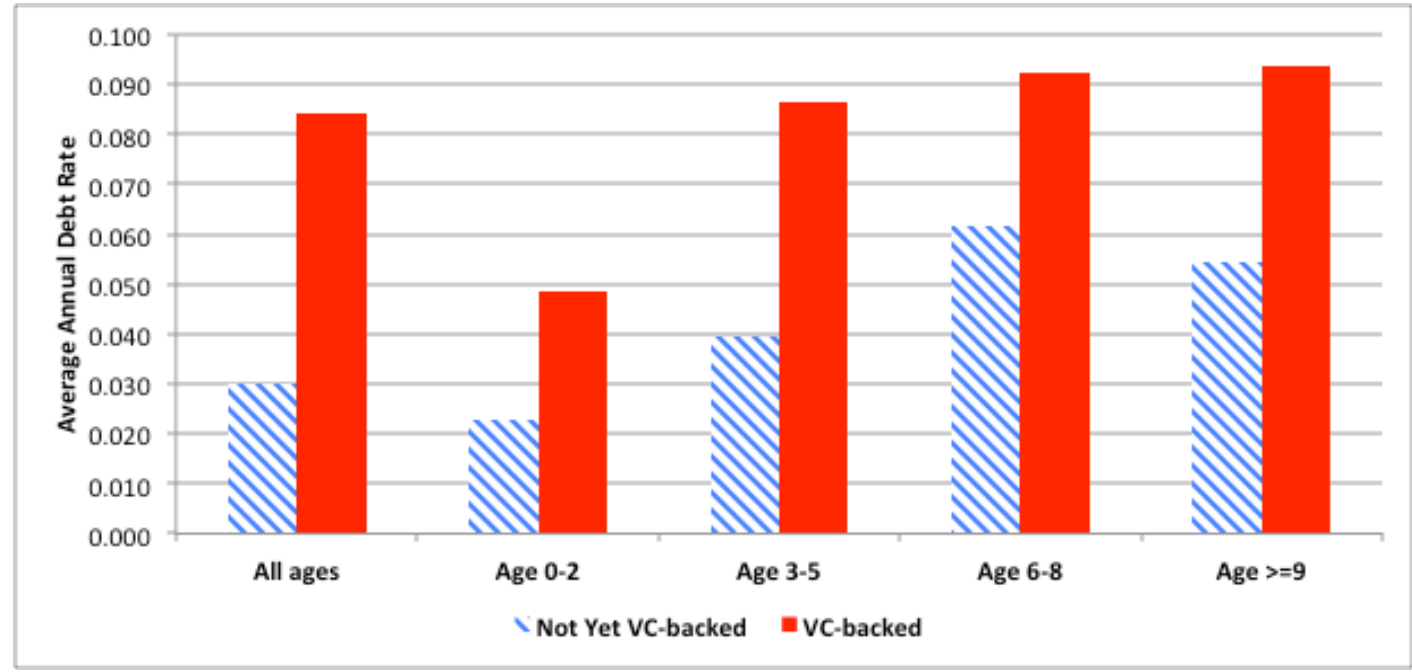

Note: Average annual debt rate is the sample probability of startups securing a loan in a given year. 
Figure 3. Non-Parametric Differences in Differences

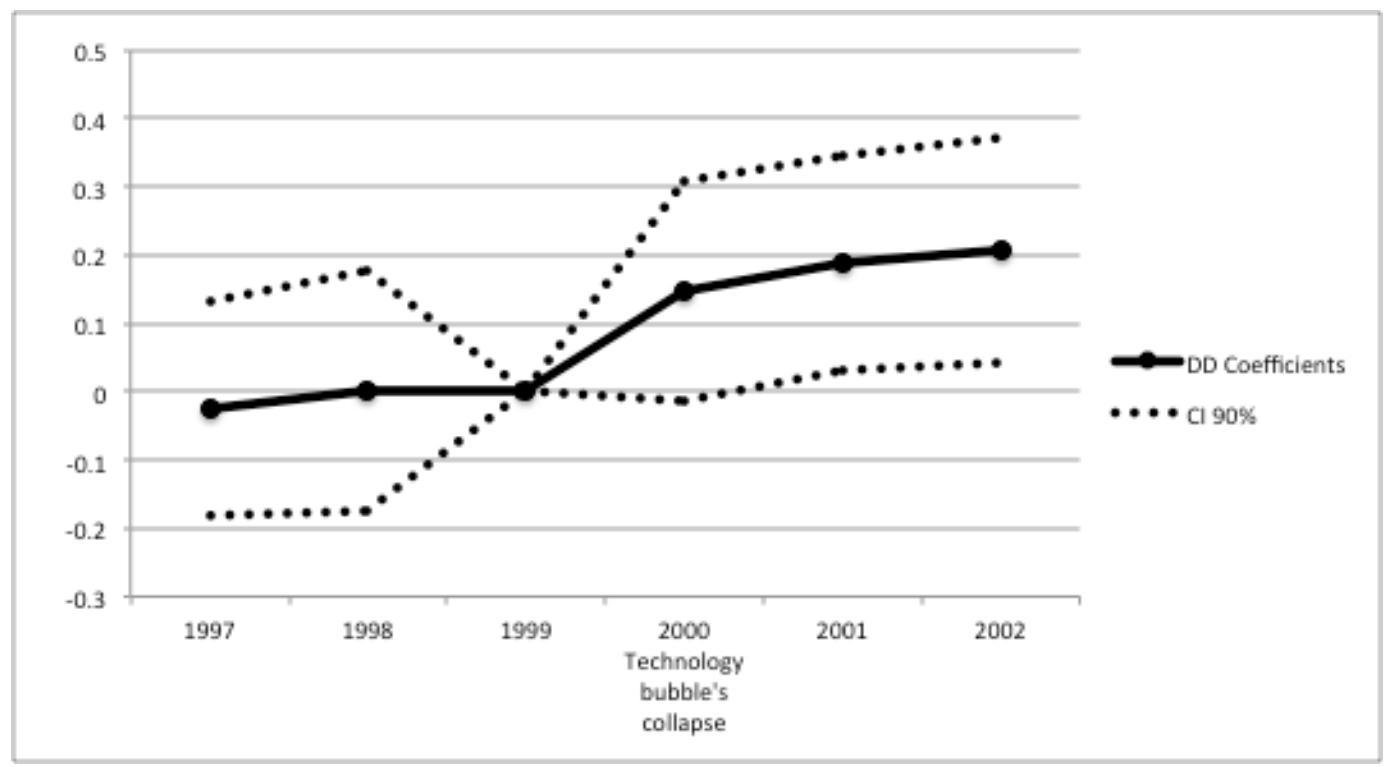




\section{APPENDIX I}

Table A.1. Main Variables and Data Sources

\begin{tabular}{|c|c|c|}
\hline & Definition & Data Source \\
\hline \multicolumn{3}{|l|}{ Dependent Variable } \\
\hline$D E B T_{i t}$ & $\begin{array}{l}\text { Indicator set to } 1 \text { if at least one patent awarded } \\
\text { to startup } i \text { is involved in a "security interest" } \\
\text { agreement (i.e., used to secure a loan) in year } t\end{array}$ & $\begin{array}{c}\text { USPTO } \\
\text { Assignments Data }\end{array}$ \\
\hline \multicolumn{3}{|c|}{ Main Independent Variables } \\
\hline Post $V C_{i t}$ & $\begin{array}{l}\text { Indicator that switches from zero to one in } \\
\text { the year that the startup first receives VC } \\
\text { financing }\end{array}$ & VentureOne \\
\hline Has Top-Tier $V C_{i t}$ & $\begin{array}{l}1 \text { if the startup is backed by a VC in the top } 5 \\
\text { percent of the annual LJP reputation score } \\
\text { distribution (sometimes time-invariant; see } \\
\text { notes on output tables) }\end{array}$ & LPJ2011 \\
\hline Recent Fund & $\begin{array}{l}1 \text { if the average age of the youngest funds } \\
\text { managed by a startup's investors in the year } \\
2000 \text { is less than } 5 \text { years old }\end{array}$ & PREQIN \\
\hline Patent Market Liquidity ${ }_{\mathrm{it}}$ & $\begin{array}{l}\text { startup } i \text { 's combined probability (averaged } \\
\text { across patents in its portfolio as of year } t \text { ) } \\
\text { that patents issued in the prior } 8 \text { years in its } \\
\text { sector are traded by year } t\end{array}$ & $\begin{array}{c}\text { USPTO } \\
\text { Reports }{ }^{\mathrm{a}} \text {; Graham } \\
\text { and Vishnubhakat } \\
(2013)^{\mathrm{b}} ; \text { RPX } \\
\text { Corp }\end{array}$ \\
\hline Firm-Specificity ${ }_{i t}$ & $\begin{array}{l}\text { Proxy for degree to which the value of } \\
\text { startup } i \text { 's patents are "firm-specific"; } \\
\text { measured as the share of patents citing } \\
\text { startup } i \text { 's patents within three years that are } \\
\text { made by the focal startup (i.e., are "self- } \\
\text { cites"). In the few instances where no patents } \\
\text { within a startup's portfolio are cited within } \\
\text { three years, the variable is missing. }\end{array}$ & $\begin{array}{c}\text { USPTO } \\
\text { patent data }\end{array}$ \\
\hline \multicolumn{3}{|c|}{ Additional Startup-Level Covariates } \\
\hline $\begin{array}{l}\text { Patent Portfolio Size } \\
\text { (citation weighted })_{i t}\end{array}$ & $\begin{array}{l}\text { Cumulative \# successful U.S. patent } \\
\text { applications of startup } i \text { by year } t \text {, weighted } \\
\text { by the \# of citations each patent receives } 3 \text { - } \\
\text { years post-grant }\end{array}$ & Delphion \\
\hline $\begin{array}{l}\text { Funds raised last equity } \\
\text { round }_{\text {it }}\end{array}$ & $\begin{array}{l}\text { Millions of US\$ raised in startup } i \text { 's last } \\
\text { equity financing round as of year } t\end{array}$ & VentureOne \\
\hline Founding Year $_{i}$ & Year startup $i$ was founded & VentureOne \\
\hline Sector $_{i}$ & $\begin{array}{l}\text { Startup } i \text { 's primary sector: medical devices, } \\
\text { semiconductor devices, or software }\end{array}$ & VentureOne \\
\hline Time Period $_{t}$ & $\begin{array}{l}\text { Indicates if year is in pre-boom (1987-1997), } \\
\text { boom (1998-1999), or post-boom (2000- } \\
2008) \text { period }\end{array}$ & VentureOne \\
\hline
\end{tabular}

${ }^{a}$ The list of class-subclass combinations relevant for medical device inventions is available from the USPTO website at: http://www.uspto.gov/web/offices/ac/ido/oeip/taf/meddev.htm. A parallel list for semiconductor devices is at: http://www.uspto.gov/web/offices/ac/ido/oeip/taf/semicon.htm.

${ }^{\mathrm{b}}$ The class-subclass list relevant for computer software invention, equivalently compiled by USPTO examiners, is reported in Graham and Vishnubhakat (2013) on page 75, footnote 7. 